\title{
Hz. Âdem'e Öğretilen İsimler: İslâmî İlimlerde Dilin Kökeni, Modern Bilimlerde Dilin Önemi
}

\section{The Names Taught to Adam: Origin of the Language in Islamic Sciences, Importance of the Language in Modern Sciences}

\author{
Ferruh KAHRAMAN \\ Doç. Dr. Dokuz Eylül Üniversitesi, Illahiyat Fakültesi, Temel İslâm Bilimleri Anabilim Dalı \\ Assoc. Prof. Dokuz Eylül University, Faculty of Divinity, Department of Basic Islam Sciences \\ İzmir, Turkey \\ ferruh.kahraman@deu.edu.tr \\ orcid.org/0000-0002-5104-8325
}

\begin{abstract}
Makale Bilgisi / Article Information



Atıf / Cite as

Kahraman, Ferruh. "Hz. Âdem'e Öğretilen İsimler: İslâmî İlimlerde Dilin Kökeni, Modern Bilimlerde Dilin Önemi". Bülent Ecevit Üniversitesi Illahiyat Fakültesi Dergisi 8/2 (2021), 355-384.

Doi: 10.33460/beuifd.975088

İntihal / Plagiarism

Bu makale, en az iki hakem tarafından incelendi ve intihal içermediği teyit edildi.

This article has been reviewed by at least two referees and scanned via a plagiarism software.

Yayın Hakkı / Copyright ${ }^{\circ}$

CC BY-NC-ND 4.0 | Zonguldak Bülent Ecevit Üniversitesi, İlahiyat Fakültesi tarafından yayınlanmıştır. Telif ve yayın hakları, Creative Commons Atıf-Gayri Ticari-Türetilemez 4.0 lisansının hüküm ve koşullarına tabidir.

CC BY-NC-ND 4.0 | Published by Zonguldak Bulent Ecevit University. Copyrights are subjected to the terms and conditions of a Creative Commons Attribution-NonCommercial-No Derivatives License 4.0.
\end{abstract}

Öz: Çalışmanın konusu Hz. Âdem'e öğretilen isimler ve bu isimlerin dille ilişkisidir. Problemi ise Hz. Âdem'e öğretilen isimlerin dil olup olmadığıdır. İslâm âlimleri ta'lîmü'lesmâya üç türlü yorum getirmiştir ki bunlar; varlığın isimleri, insanın kabiliyeti ve insanın konuşma özelliği dildir. Bu çalışmada ta'lîmü'l-esmâya getirilen üçüncü görüş yani insanın dil üretme becerisi üzerinde durulacaktır. Ehl-i Sünnete göre Yüce Allah isimlerle Hz. Âdem'e ilk dil olan köken dili öğretmiş; insanlar da tarihsel süreç içerisinde bu dilden diğer dilleri türetmişlerdir. Mu'tezile'ye göre ise Hz. Âdem'e öğretilen isimlerden kasıt insana dil oluşturma kabiliyetinin verilmesidir. Buna göre Ehl-i Sünnet, ilk dilin ilâhî bildirimle öğretildiğini savunarak tevkîfiliği; Mu'tezile ise uzlaşıyla oluştuğunu söyleyerek ıstılâhîliği savunmuştur. Dilin tevkîfî ve ıstılâhî olduğuna dair tartışmaları ilk yazılı kaynaklarda görmekle beraber günümüz felsefe, toplum ve dil bilimlerinde de bu tartışma devam etmektedir. Çalışmada İslâm âlimlerinin görüşlerini tespit etmede tefsirci, kelâmcı, filozof ve dilcilerin görüşleri ele alınırken toplum bilimlerinde sosyolog, psikolog, filolog ve filozofların görüşlerine yer verilmiştir. İslâm âlimleri; isimler ve dil 
konusuna yaratılış teorisine göre yaklaşmışlar; insanın konuşmasını ta'lîmü'l-esmâ âyeti ve mürâdifleri bağlamında değerlendirmişlerdir. Modern bilim insanları ise dili doğalcılık ve uzlaşı teorisine göre açıklamışladır. Çalışmanın önemi, dilin mahiyeti ve kökeninin İslâm âlimleri ile modern bilim insanlarının görüşlerinin karşılaştırmalı olarak incelenmesidir. Amacı ise ta'lîmü'l-esmâ âyetini dille ilişkilendiren İslâm âlimlerinin naklî açıklamalarının geçerliliğini modern bilimlerin somut verileriyle mukayese etmektir. Araştırma sonucunda görülmüştür ki alanı ne olursa olsun seküler tüm toplum bilim paradigmaları dil üzerinde durmuşlar ve teorilerini dil etrafında şekillendirmişlerdir. $\mathrm{Bu}$ da isimlerden haber vermekle meleklerin hayran kaldığı Hz. Âdem'in ve insanın üstün konumunu ortaya koymakta; isimleri dille açıklayan İslâm âlimlerinin tevillerinde ne kadar haklı olduklarını göstermektedir.

Anahtar Kelimeler: Tefsir, Âdem, Dil, Dilbilim, Köken, Toplum, Tevkîfî, Istılâhî.

Abstract: The subject of the study is the names taught to Prophet Adam and their relationship with the language. Its problem is whether the names taught to Prophet Adam are languages. Islamic scholars have brought three types of interpretations to ta'limü'l-asmä/the names taught to Adam, which are the names of being, the ability of man and the ability of man to speak. In the present study, the third opinion brought to the names taught to Adam, that is, the ability of a person to produce language will be focused on. According to the Ahl al-Sunnah, Almighty Allah taught Prophet Adam the language of origin, which is the first language; people also derived other languages from this language in the historical process. According to Mu'tazila, from the names taught to Prophet Adam, the intention is to give man the ability to create a language; according to them, languages are created by man's own ability. Accordingly, Ahl al-Sunnah defended tevkifi/taught by God, arguing that the first language was taught by divine notification, and Mu'tezile defended istilähi/humans learned by themself, saying that it was formed by compromise. Although discussions about the tevkifi and istılähi of language are seen in the first written sources, the discussion continues in today's Philosophy, Social and Linguistic Sciences. In determining the views of Islamic scholars, the views of commentator, theologian, philosophers and linguists are included in the study; while the views of sociologists, psychologists, philologists and philosophers are included in the social sciences. Islamic scholars; they approached the subject of names and language in the course of the theory of creation; they evaluated the speech of man in the context of the verse of the names taught to Adam and synonyms. Modern scientists, on the other hand, have explained the language according to the theory of naturalism and compromise. The importance of the study is that the nature and origin of language is examined by the views of Islamic and modern scientists. The present study aims to test the validity of the explanations of the Scriptures of Islamic scholars who associate the verse of the names taught to Adam / with language with the concrete data of modern sciences. As a result of the research, it has been shown that all secular social science paradigms, regardless of their field, have focused on language and shaped their theories around language. This Is A Prophet that the Angels admire by reporting on the names. It reveals the superior position of Adam and man whom the Angels admire, also shows how justified the Islamic scholars who explain the names in language are in their comment.

Keywords: Tafsìr, Adam, Language, Linguistic, Origin, Society, Tevkiffi, Istılähì. 


\section{Giriş}

Dil; İslâmî ilimler ile modern bilimlerde ${ }^{1}$ üzerinde durulan önemli bir konu, insanî bir özellik ve toplumsal bir kurumdur. Zira dil; bir yandan Yüce Allah'ın ilim, kudret ve tasarrufuna işaret ederken diğer yandan da insanın iradesi, yeteneği ve fiillerine işaret etmektedir. Hatta benlik, toplumsal yapı ve kültür dille oluşmaktadır. Bu nedenle hem İslâmî ilimlerde hem de modern bilimlerde dil merkezî önemini korumuştur. Ancak her iki bilim paradigması dile farklı yaklaşmış; tefsirciler, kelamcılar ve İslâm felsefecileri meseleyi dilin mahiyeti ve kökeni üzerinden değerlendirmişlerdir. Modern bilim insanları ise dilin önemi üzerinde durmuşlar; dili toplumsal bir kurum, benliğin inşacısı, insanlar arası etkileşim aracı, toplumsal bir olgu ve bir kültür unsuru olarak açıklamışladır.

İslâmî ilimler içerisinde dilin mahiyeti ve kökeni; ta'lîmü'l-esmâ olarak adlandırılan "Âdem'e isimleri öğretti" âyeti bağlamında şekillenmiştir. ${ }^{2}$ Beşerî sorumluluk ve peygamberlik dil üzerine inşa edilmiş; i ilâhî emir ve nehiyler dille ifade edilmiş, ${ }^{4}$ Yüce Allah dille anılmış; ${ }^{5}$ Kur'ân dille indirilmiş ${ }^{6}$ ve Hz. Îsâ gibi bazı peygamberlere kelâmullah lakabı verilmiştir. '̇ slâmî kutsal metinlerin dile önem vermesi Müslümanları dil çalışmalarına sevk etmiştir. Dil üzerine çalışmalar yapan âlimlerin çoğunluğu dilin önemli insanî bir özellik olduğunu ve Hz. Âdem'e ilâhî olarak öğretildiğini belirtmişlerdir. Öğretilen bu dilin hangisi olduğu konusunda ihtilaf eden ulemâ, genel olarak tercihini kadîm Arapçadan yana kullanmıştır. ${ }^{8}$ Âlimler içerisinde Süryanice diyenler olsa da Arapça ile Süryanice kadîm Arapçadan doğmuş dillerdir. İnsanoğlu Mekke'den tüm dünyaya yayılmaya başladığında kuzeye, Mezopotamya'ya ve Bilâdü'ş-Şâm'a yerleşenler Süryanice gibi kadîm Arapçanın farklı lehçelerini kullanmaya başlamışlar; güneye ve Yemen tarafına yerleşenler ise kadîm Arapçaya bağlı kalarak günümüze kadar varlığını devam ettirmişlerdir. Bazı âlimler de Hz. Âdem'e tüm dillerin tevkîfî olarak öğretildiğini iddia etmişlerdir. ${ }^{9}$ Ancak bu görüşü, tüm diller için değil de bütün dillerin kökeni olan kadîm Arapça olarak anlamak daha mantıklıdır. Zira bir insanın, tarihin başlangıcında tüm dilleri bilmesinin bir anlamı yoktur. Tüm diller ifadesini insanın dil

1 İlim ile bilim birbiri yerine kullanılsa da teknik olarak aralarında fark vardır. "ilim" alanı fark etmeksizin İslâmî bir yöntemle yaratıcıya gönderme yapan düzenli bir bilgi dizgesi iken "bilim" din ve yaratıcının pek önemli olmadığı, sadece olguları açıklamaya dayalı bir bilgi anlayışıdır. Zira ülkemizde seküler yaklaşıma geçmeden önce ilim tabiri kullanılırken modernleşmeyle beraber bilim ibaresi kullanılmıştır. Çalışmada bu teknik farka dikkat etmekle beraber örfî kullanımında olduğu gibi bazen birbiri yerine de kullanılmıştır. “ilim”in tanımı için bk. Ali b. Muhammed Cürcânî, Şerhu'I-mevâkıf (İstanbul: Dârü't-Tıbâati'I-Âmire, 1321/1905), 1/209-213; “Bilim”in tanımı için bk. Doğan Özlem, Bilim Felsefesi (İstanbul: Notos Yayınları, 2019) 28.

el-Bakara 2/31.

İbrâhim 14/4.

Ebû Mansûr Abdülkāhîr el-Bağdâdî, el-Fark beyne'l-firâk ve beyâni'l-firaki'n-nâciye (Beyrut: Dârü'l-Afâk Şâmile, 1977), 332.

5 Ebû İshâk İbrâhîm b. es-Serî b. Sehl ez-Zeccâc, İștikaku esmâillah, Thk. Abdul Hüseyin Mübarek (Beyrut: Müessesetü'r-Risâle, 1986), 88.

el-Beled 90/9.; er-Rûm 30/22.

Âl-i İmrân 3/45, en-Nisâ 4/171.

Kadîm Arapçaya günümüzde Sâmî dili denilmektedir.

Luay Hatem Yaqoob, "İslâmî Kaynaklar Açısından Peygamberlerin Konuştuğu Diller" Cumhuriyet Ilahiyat Dergisi 25/1 (Haziran 2021), 391, 392. 
oluşturma özelliği olarak anlamak daha uygundur. Muhtemelen Hz. Âdem'e bir dil öğretilmiş; insan da Yüce Allah'ın kendisine verdiği üstün özelliklerle tarihsel süreçte ve doğal olarak bu dilden diğer dilleri oluşturmuştur. Bu İslâmî görüşün bir benzeri Ahd-i Atîk ile Babil mitolojilerinde de geçmektedir. Ahd-i Atîk'teki bir bilgiye göre tanrı insanlara belli isimler takdir etmiş; insanlar ise bunu beğenmeyerek kendilerine yeni isimler vermişlerdir. ${ }^{10}$ İslâmî açıdan ise isimleri beğenme diye bir şey yoktur. İslam'da insana isimlerin verilmesi; insanın dil ve kültür üreticisi bir varlık olduğunun açıklamasıdır. ${ }^{11}$

Felsefî düşüncede ise dilin nerede ve nasıl ortaya çıktığı ile ilgili farklı görüşler ortaya atılmıştır. ${ }^{12}$ Herakletios (M.Ö. 475) dilin tevkîfî/ilâhî/ilhâmî olduğunu ifade etmiştir. ${ }^{13}$ Sokrates (M.Ö. 399) mekik-marangoz örneğinden hareketle nesnelere uygun ismi, erbabının vermesi gerektiğini savunmuş ve görüşünü Homeros'tan alıntılarla desteklemiştir. ${ }^{14}$ Sokrates bu açıklamalarıyla dil konusunda uzlaşmacılık görüşüne yakın bir tutum sergilemiştir. Platon da (M.Ö. 347) dil konusuna değinmiş; isimleri düşüncelerin taşıyıcısı olarak kabul etmiş; isim ile nesnenin aynı şey olup olmadığını tartışmıştır. ${ }^{15}$ Platon isimleri; doğalcılık ve uzlaşmacılık görüşleri etrafında iki farklı bakış açısıyla ele almıştır. Doğalcılık kuramına göre isimler; varlığın adları olup onun özüyle alakalı şeylerdir. ${ }^{16}$ Platon, hocası Sokrates'le dillerin doğal olup olmadığı meselesini tartışmış; tercihini uzlaşmacılıktan yana kullanmıştır. Uzlaşmacılık görüşüne göre isimler insanlar arası sözleşmenin bir sonucudur. İnsanlar tarihin bilinmeyen bir döneminde varlıklara isimler vermiş; bu isimler de varlıkların adları olmuştur. ${ }^{17}$ Tarihsel süreç içerisinde de insanlar bu isimler üzerinde değişiklik yapmışlardır. Platon'a göre insanlar, isimler üzerinde değişiklik yapma özelliğine sahip olsalar da bu işi diyalektik düşünceye sahip filozoflara veya sanatçılara bırakmak en doğrusudur. Aristotales (M.Ö. 322) ise sözleşmeyle oluşan isimlerin varlıkları ne kadar temsil edip etmediğini tartışmış; duyuların varlığı algılaması ile anlamların zihinde oluşmasının tüm insanlarda aynı olduğunu belirtmiş; ancak adlandırmanın toplumdan topluma değiştiğini söylemiştir. Dilin kökeni konularına da değinen Aristotales, Platon gibi muvâda'/sözleşme/ ıstılâhilîlik yaklaşımını tercih etmiş̧tir. ${ }^{18}$ Yine başka bir Yunan filozofu Demokritos (M.Ö. 370) da ıstılâhilîği kabul etmiş; nesnelerin isimlendirilmesinde toplumsal uzlaşıya vurgu yapmıştır. ${ }^{19}$

10 Kitâb-ı Mukaddes (İstanbul: Kitab-ı Mukaddes Şirketi, 2003), Yaratılış 2/19-20.

11 bk. Ferruh Kahraman, "Hz. Âdem'e Öğretilen İsimler: Kültür Olgusunun Sembolik Söylemi", Edebali İslamiyat Dergisi 4/2 (Kasım/2020).

12 Merih Zıllığlu, Iletişim Nedir? (İstanbul: Cem yayınları, 1996), 123-126.

13 Aktaran. Mustafa Sâdık er-Râfi', Târihu edebi'l-Arab (Beyrut: Dâru'I-kitâbi'l-Arabî, 1999), 57.

14 Plato, "Cratylus", Complete Works, 388e-392c.

15 Doğan Aksan, Her Yönüyle Dil: Ana Çizgileriyle Dilbilim (Ankara: TDK, 2003), 1/55-57.

16 Plato, "Cratylus", Complete Works: Dijital Edition, ed. John M. Cooper (Indianapolis: Phackett Publishing Company, 1997), 384a, 387c-d, 435d-e.

17 Plato, "Cratylus", Complete Works, 384d-e.

18 Aristotle, “De Interpretatione”, Complete Works: Digital Edition, ed. Jonathan Barnes (New Jersey: Princeton University Press, 1995), 16a 26-29.

19 Dilin farklı paradigmalar ve dönemler açısından analizi için bk. Ramazan Demir, Arap Dilbilimcilerine Göre Dillerin Kaynağı Meselesi: Hz. Âdem'in Dili (İstanbul Hâcegân Akademi Kitaplığı, 2009), 1-209. 
Modern dönemde ise dile farklı yaklaşımlar olmuş; klasik dönemden farklı dil teorileri geliştirilmiştir. Wittgenstein (ö. 1951) dilin toplumsal yönü üzerinde durmuş; dilin zihinsel olmaktan ziyade toplumsal hayatın içerisinde gözlemle ve simgelerle öğrenildiğini belirtmiştir. ${ }^{20}$ Foucault (ö. 1984) dil, söylem ve iktidar üzerinde durmuş; bireylerin söylemle inşa edildiğini ve kontrol edildiğini ifade etmiştir. Foucault'ya göre maddî ve manevî herhangi bir şeye sahip olmak aslında dile ve söyleme sahip olmaktır. ${ }^{21}$ Bunun yanında Wilhelm von Humboldt, (ö. 1835) Nöldeke (ö. 1930) Bloomfield, (ö. 1949) ve Chomsky gibi dilbiliminde yetkin bilim insanları yetişmiş̧tir. Saussure, (ö. 1913) Sapir, (ö. 1939) Jakobson, (ö. 1982) ve Umberto Eco (ö. 2016) gibi araştırmacılar ise daha çok dil teorileriyle meşhur olmuşlardır. ${ }^{22}$ Bu çalışmada ise İslâm âlimleri ile modern bilim adamlarının dil konusundaki görüşleri karşılaştırılmıştır. Konunun sınırlılığından dolayı İslâmî ilimler içerisinde tefsir, kelâm ve felsefe alanında öne çıkan âlimlerin görüşleri değerlendirilirken modern bilimlerde ise daha çok sosyoloji, psikoloji, antropoloji ve kültür tarihi alanındaki bilim insanlarının çalışmalarına müracaat edilmiştir. Böylece İslâm ile modern iki farklı bilimsel paradigmaların dile yaklaşımları mukayese edilmiş; tefsirci, kelamcı, sosyolog ve psikolog gibi bilim insanlarının dil nosyonları açıklanmaya çalışılmıştır.

\section{1. İslâmî illimlerde Hz. Âdem'e Öğretilen İsimler ve Dil}

İslâmî ilimlerin özgün gelişimi içerisinde Ebû Osman Câhız (ö. 255/869) ve Ebû Hasan eş-Şi'rî (ö. 324/933) gibi âlimler ilk defa köken dil üzerinde durmuşlar; köken dilin tevkîfî ve Arapça olduğunu savunmuşlardır. ${ }^{23}$ Daha sonra İbn Fârîs (ö. 395/1004) Hz. Âdem'in konuştuğu dili sorgulamış; dillerin çeşitlenmesi konusunda görüş bildirmiş ve tevkîfîliği savunmuştur. ${ }^{24}$ İlerleyen süreçte dilciler; köken dilin nasıl ortaya çıktığı konusunda tevkîfilik, doğalcılık ve ıstılâhîlik olmak üzere üç farklı bakış açısına sahip olmuşlardır. Doğayı taklit anlamına gelen doğalcılık yaklaşımı İbn Cinnî (ö. 392/1002) tarafından kabul görürken ${ }^{25}$ Istılâhîlik ise Mu'tezilîler tarafından kabul görmüştür. ${ }^{26}$

Kelâmcılar meseleye Allah'ın isimleri etrafında yaklaşmışlar; tevkîfillik, ıstılâhîlik ve tevakkuf olmak üzere farklı boyutlardan değerlendirmişlerdir. ${ }^{27}$ Felsefeciler de isimleri bir başka boyut olarak kabul edilebilecek meleke teorisi bağlamında ele almışlardır. ${ }^{28}$ İsim ve dil konusunda Ehl-i Sünnet daha çok tevkîfîliği; Mu'tezile ise beşerî uzlaşıyı; filozoflar da meleke kuramını savunsalar da bunu genellemek indirgemeci bir bakış açısı olacaktır. Zira Ehl-i Sünnet, tevkîfîliği savunurken dildeki ilâhî lütfa; Mu'tezile ıstılâhîlikle beşerî iradeye vurgu yapmakta; felsefeciler

20 Ludwig Wittgenstein, Felsefi Soruşturmalar, çev. Deniz Kanıt (İstanbul: Totem Yayıncılık, 2006), 10-70.

21 Michel Foucault, The Archeology of Knowledge (New York: Random House, 1972), 138.

22 bk. Zeynel Kıran - Ayşe Kıran, Dilbilime Giriş (Ankara: Seçkin Yayınları, 2018), 201-289.

23 Râfi', Târihu edebi'l-Arab, 57.

24 Süyûtî, el-Müzhir, 1/13.

25 İbn Cinnî, el-Hasâis, nşr. Muhammed Ali en-Neccâr (Beyrut: Dâru'l-kitâbi'l-Arabî, 1376/1956), 1/69-73.

26 Râfi', Târihu edebi'l-Arab, 63.

27 Ebû Bekr Muhammed b. Tayyip el-Bâkıllânî, et-Takrîb ve'l-irşâd (Müessesetü'r-Risâle, 1998), 1/319-321; Ebü'lMuîn en-Nesefî, Tabsıratü'I-edille fî ûsûli'd-dîn, thk. Hüseyin Atay (Ankara: Diyanet İşleri Başkanlığı Yayınları 2003), $1 / 474$.

28 Ebu Nasr el-Fârâbî, Harfler Kitabı, çev. Ömer Türker (İstanbul: Litera Yayınları, 2008), 75. 
ise meleke yaklaşımıyla aklî ve istidlâlî ameliyeyi öne çıkarmaktadırlar. Diğer yandan Ehl-i Sünnet, Mu'tezile ve meşşâîler belli bir ekolün adıdır. Bu ekoller çok sayıda bireylerden oluştuğu için grup içi farklılıkların olması ve karşıt görüşleri kabul eden âlimlerin de olması çok tabiîdir. Mesela tevkîliği savunan Nesefî (ö. 508/1115) ıstılâhîliği de ihmal etmemiş; ilk dilden sonraki dilleri insanların sözleşme ile oluşturduğunu belirtmiştir. ${ }^{29}$ Cüveynî (ö. 478/1085) Yüce Allah'ın isimleri ve dilin tevkîfî yönü üzerinde durmuş; daha sonraki dillerin bu kök dilden sözcük ve sîğaların türetilmesiyle oluştuğunu ifade etmiştir. ${ }^{30}$ Çocukların ana-babası ve çevresinden dil öğrenmesini delil gösteren Cüveynî; dil, benlik ve sosyalleşme arasındaki ilişkiye de dikkat çekmiştir. ${ }^{31}$ Onun tevkîfî ve ıstılâhî açıklamalarına bakıldığında Hz. Âdem'e öğretilen ilk dilin ilâhî; diğerlerinin ise beşerî olduğu anlaşılır. Sonraki nesillerde ana-baba ve toplum tarafından gerçekleştirilen benlik ve toplumsallaşma; Hz. Âdem'de bizzat Yüce Allah tarafından gerçekleştirilmiştir. Gazzâlî (ö. 505/1111) dil ve isim konusunu Yüce Allah'ın isimleri bağlamında açıklamış; kök dilin tevkîfí; diğer dillerin ise bu kök dilden türetildiğini kabul etmiştir. ${ }^{32}$ Gazzâlîyye göre Yüce Allah insanları dil oluşturma kabiliyetiyle birlikte yaratmıştır ki mevcut durum da bunu ispatlamaktadır. ${ }^{33}$ Bu sebeple dillerin başlangıçta ilâhî yönü olsa da sonrasında beşerî yönünü kabul etmek gerekir. Gazzâlî el-Mustasfâ adlı eserinde dille ilgili üç görüşten bahsettikten sonra bunların her üçünün de aklen mümkün olduğunu söylemiştir. İlk dilin tevkîfîliğini savunan Fahreddîn Râzî (ö. 606/1210) ve Siraceddîn Urmevî (ö. 682/1283) gibi âlimler de dilin beşerî yönünü ihmal etmemişlerdir. ${ }^{34}$ Müfessirler ise $\mathrm{Hz}$. Âdem'e öğretilen isimleri, varlığın adları, insanın konuşma melekesi dil ve kültür üretme (yeryüzünü imâr ve ıslâh) özelliği olarak yorumlamışlardır. ${ }^{35}$

\subsection{Müfessirlere Göre Hz. Âdem'e Öğretilen İsimler}

İslâmî ilimler içerisinde isimler ve dil konusu, müfessirler tarafından ta'lîmü'lesmâ âyeti bağlamında ele alınmıştır. İlk dönem müfessirlerinden Katâde (ö. 117/735) ve Hasan Basrî (ö. 110/728) isimleri "at, katır, deve, cin ve diğer varlıkların adı olarak açıklamışladır. ${ }^{36}$ Bir başka rivayette de Katâde ve Dahhâk'ın (ö. 105/723) ta'lîmü'l-esmâ yı; insanların, hayvanların, kara, dağ ve deniz gibi pek çok varlığın adı olarak açıkladığı belirtilmektedir. ${ }^{37}$ Mücâhid (ö. 103/721) isimlerin "karga ve güvercin gibi tüm varlıkların adları" olduğunu; Said b. Cübeyr (ö. 94/713) de "deve, inek, koyun gibi evcil hayvanların adları" olduğunu belirtmiştir. Said b. Ma’bed (ö.

29 Nesefî, Tabsıratü'l-edille fî ûsûli'd-dîn, 1/474.

30 Ebü'l-Meâlî Rüknüddîn Abdülmelik b. Abdillâh b. Yûsuf el-Cüveynî, el-irşâd, thk. Saîd Temîm (Beyrut: Müesseseti'l-Kütübü's-Sekāfe, 1416), 46.

31 Soner Gündüzöz, Arapça'da Kelime Türetimi, (Samsun: Din ve Bilim Kitapları Yayıncılık, 2005), 244.

32 Ebû Hâmid Muhammed b. Ahmed el-Gazzâlî, el-Mustasfâ, thk. Muhammed Abdüsselâm (Dârü'l-Kûtûbi'lIIlmiyye, 1993), 1/180-182; Ebû Bekr b. Muhammed el-Hudayrî es-Süyûtî, el-Müzhir fi ulûmi'l-luga ve envâi'hâ (Beyrut: Dârü'l-Kütübi'l- 'illmiyye, 1998), 1/23.

33 Ebû Hâmid Muhammed b. Ahmed el-Gazzâlî, Maksadü'l-esnâ fi şerhi meâni esmâillahi'l-hüsnâ, thk. Bessam Abdulvahab el-Camî, (Kıbrıs: el-Cifan ve'l-Cabi, 1987), 7-10.

34 Süyûtî, el-Müzhir, 1/18.

35 Muhammed Mahmûd el-Hicâzî, et-Tefsîru'l-vâdıh (Beyrut: Dâru'I-Cîli'l-Cedîd, 1413), 1/31; Muhammed Ali esSâbûnî, Tefsîru'l-Fâtiha ve'l-Bakara (Arabistan: Dâru İbn Cevzî, 1423), 1/119.

36 İbn Cerîr et-Taberî, Câmiü'I-beyân (Beyrût: Dâru'l-Kütübi'I-'Illmiyye, 2009), 1/252.

37 Muḳāil b. Süleymân, Tefsîru Muḳātil b. Süleymân (Beyrût: Dâru Ị̇̂âai't-Türâsi'l-'Arabî, 2002), 1/98. 
150/767) ise İbn Abbâs'tan (ö. 68/688) rivayetle isimleri “insanın düşünme, konuşma potansiyeli ile iletişim vasıtası olan kelimeler olduğunu söylemiştir. ${ }^{38}$ Buna göre isimler; insandaki dil, konuşma potansiyeli ve düşünme özelliğidir. Nitekim Yüce Allah, Hz. Âdem'e ruhundan üflemiş; ona düşünme, iletişim ve yaratıcılık yeteneği vermiştir. ${ }^{39} \mathrm{Bu}$ yetenek, insana potansiyel olarak verilmiştir. Bu potansiyel; ona isimlerin öğretilmesiyle işlerlik kazanmıştır. İnsanın düşünme özelliğinin olması; onun gelişmiş bir sinir sistemi ile kuvvetli bir zihne sahip olması anlamına da gelmektedir. Bu nedenle ta'lîmü'l-esmâ 'dan önceki âyette insanın halifeliğinden bahsedilmiştir. ${ }^{40}$ Halifelik insanın diğer varlıklara hükümran olmasıdır. Mâtürîdî'ye (ö. 333/944) göre bir varlığın halife olabilmesi için zihin, dil, düşünme ve yaratıcılık gibi bazı özelliklere sahip olması gerekir ki başta kendi olmak üzere varlıklarla ilgili tasarruflarda bulunabilsin. İsimler sadece varlığın adlarına değil insanın potansiyeli olan dile, dille konuşmaya, muhakeme yapmaya, düşünmeye, doğayı dönüştürmeye ve yaratıcılığa da vurgu yapmakta; insanının potansiyelini ortaya çıkaran unsurlara işaret etmektedir. Bu unsurlar da insana ilâhî bir bildirimle/tevkîfi olarak öğretilmiştir. İsimlerin öğretilmesi Hz. Âdem'le beraber başlamış; tarihsel süreç içerisinde çeşitlenerek ve genişleyerek pek çok dilin oluşmasına zemin hazırlamıştır. ${ }^{41} \mathrm{M}$. Ali es-Sabûnî ve onu takip eden bazı âlimlere göre isimlerin insanın kültür üreticisi olmasına, yeryüzünü imara ve varlıklardan yararlanmayı öğrenmesine de işaret etmektedir. ${ }^{42}$ Mahmud el-Hicâzî de bu minvalde insanın kültürel bir varlık olmasına; dünyayı imar ve ıslah görevinin ona verilmesine işaret ettiğini belirtmiş̧tir. ${ }^{43}$ Buna göre isimler insana öğretilen tüm varlığın adları ile kültür üretmesi ve doğayı dönüştürmesi anlamlarına gelmektedir. İslâm ilim tarihi içerisinde tefsirden sonra kelâm ilminde de isimler konusuna sıkça değinilmiş̧ir.

\subsection{Kelâmcılara Göre Hz. Âdem'e Öğretilen İsimler}

Kelâmcılar arasında ilk dil veya köken dil konusu tevkîfilik, ıstılâhîlik ve tevekkuf etrafında şekillenmiştir. Illk dil konusunda Ehl-i Sünnet kelâmcıları tercihlerini genel olarak tevkîfillik yönünde kullanmışlardır. ${ }^{44}$ Eş’arî (ö. 324-935) ilk dilin Yüce Allah'ın rahmetinin bir tecellisi olarak ilâhî bildirimle/tevkîfî olarak öğretildiğini belirtmiştir. ${ }^{45}$ Eş'arî, bu görüşüyle ıstılâhîliği iddia eden hocası Ebû Ali el-Cübbâî́ye (ö. 303-916) karşıt bir görüş benimsemiştir. Eş'arî dilin kökeninin asılda tevkîfî; fer'de ise kıyas ve ıstılâhî olabileceğini söylemiştir. ${ }^{46}$ Mâtürîdî de

38 Taberî, Câmiü'I-beyân, 1/252; Ferruh Kahraman, "Hazreti Âdem'e Öğretilen İsimler: İnsanoğlunun Gerçek Mahiyetinin Tezâhürü", Balıkesir llahiyat Dergisi 11/1 (Haziran 2020), 42, 43.

39 Kādî Nasîrüddîn el-Beyzâvî, Envâru't-tenzîl ve esrâru't-te'vîl (Beyrût: Dâru'l-Kütübi'I-'ilmiyye, 1431/2011), 1/51.

40 el-Bakara 2/30.

41 Ebû Mansûr el-Mâtürîdî, Te'vîlâtü ehli's-sünne, thk: Fatıma Yûsuf el-Haymî (Beyrût: Müessesetü'r-Risâle, 1424/2004), $1 / 34$

42 Sâbûnî, Tefsîru'l-Fâtiha ve'I-Bakara, 1/119.

43 Hicâzî,et-Tefsîru'l-vâdıh, 1/31.

44 Geniş bilgi için bk. Hamdullah Arvas, "Kelâm'da "Ta'lîm-i Esmâ”: Dil Teorileri Bağlamında İlâhî Mânaların İsimlendirilmesi Meselesi", Kader 18/2 (Aralık 2020), 505-515.

45 Fahreddîn er-Râzî, Mefâtihü'l-gayb, (Beyrut: Dârü'l-Ihyâi't-Tûrâs, 1420), 2/396; Eş'arî́nin görüşleri için bk. Muhammed b. Hasan b. İbn Furek, Mücerred makâlâti'ş-şeyh Ebi'I-Hasen el-Eş'arî, thk. Daniel Gimaret (Beyrut: Dâru'lMeşrik, 1987).

46 Takıyyüddîn Ahmed b. Abdilhalîm b. Mecdiddîn Abdisselâm İbn Teymiyye, Kitâbü'l-Îmân (Amman: Dârü'l-Beşîr, 1996), 75-76. 
dilin üstün konumuna vurgu yaparak ilâhî bir yönünün olduğunu belirtmiştir. ${ }^{47}$ Ona göre pek çok özelliğin ve evrensel değerlerin insana ilâhî olarak bildirildiği gibi dil de ilâhî olarak peygamberler vasıtasıyla insanlara öğretilmiştir. ${ }^{48}$ Nesefî (ö. 508/1115) ise meseleye daha ayrıntılı yaklaşıp köken dil ile daha sonraki dillere değinmiştir. Onun açıklamalarına göre köken dil ilâhî olarak öğretilmiş; diğer diller ise bu dilden insanlar tarafından sözleşmeye dayalı olarak geliştirilmiştir. ${ }^{49}$ Bâkıllânî ise daha geniş bir açıklamayla sadece konuşma dilinin değil; jest, mimik ve işaret dillerinin bile tevkîfî olarak öğretildiğini savunmuştur. ${ }^{50}$ Bakıllânî, $\mathrm{Hz}$. Âdem'e öğretilen isimlerin mahiyeti konusunda âlimler arasında görüş ayrılığı olduğunu belirtmiş; bazı âlimlerin isimleri "dil", bazıların da "akıl sahibi varlıkların isimleri öğrenme yetisi" olarak açıkladıklarını belirtmiştir. Zira isimler meleklere bir sınav esnasında arz edilmiştir. Bu isimlerin kapsamı ise âyette geçen küllehâ ibaresinden hareketle tüm cins ve tür olmak üzere varlığın adlarıdır. Ta'lîmü'lesmâ, hakiki anlamı ile düşünüldüğünde, Yüce Allah'ın, Hz. Âdem'e kainatta deneyimlenen varlıkların tikel bilgilerini ve tümel değerlerini öğretmesi anlamına gelmektedir. Buna göre bütün diller, Hz. Âdem'e cevher ve arazları ile birlikte öğretilmiş; ilmî gelişmeler için de nazar ve istidlâl ilminin yolları gösterilmiştir. Nazar ve istidlâl ilmiyle insanlar varlıklara yeni isimler vermişlerdir. İnsanların varlıklara yeni isimler vermesi de dilin ıstılâhî yönünün olduğunu göstermektedir. ${ }^{51}$ Bu açıklamalardan anlaşıldığına göre Ehl-i Sünnet kelâmcılarının sözleşmeyi inkâr etmemekle birlikte daha çok tevkîfillik üzerinde yoğunlaştıkları söylenebilir. İbn Hazm (ö. 456/1064) da dillerin kökeni ve inşasında tevkîfîliği savunmuştur. ${ }^{52}$ Ona göre ilk insanların ilâhî bir lütuf olmadan kendi başlarına bir dil oluşturması çok zordur. ${ }^{53}$

Mu'tezile dilin insanlar tarafından inşa edildiğini ve toplumsal sözleşmeye/ ıstılâha dayandığını savunmuştur. Mu'tezilenin ıstılâh kuramı, Kur'ân'ın mahluk olduğu görüşü etrafında şekillense de ${ }^{54}$ onların bu görüşleri, Kur'ân'daki ta'lîmü'lesmâ âyetinden ziyade Tevrât'a daha yakındır. Zira Kur'ân'da Hz. Âdem'e isimlerin Yüce Allah tarafından öğretildiği bilgisi yer alırken ${ }^{55}$ Tevrat'ta Hz. Âdem'in isimleri tanrının emriyle bizzat kendisinin koyduğu belirtilir. ${ }^{56}$ Muhtemelen Mu'tezile bu konuda klasik kaynakların aksine Tevrat'tan etkilenmiştir. Bazı kaynaklarda Ebû Ali el-Cübbâî ve onu takip eden bazı Mu'tezilîlerin tevkîfilliği benimsediği bilgisi yer alsa da sıfatlar ve ilâhî kelâm konusunda Mu'tezile ıstılâhîliği savunmuştur. ${ }^{57}$ İbn Teymiyye'ye göre Ebû Haşim el-Cübbâî (ö. 321/933) köken dil başta olmak üzere insanların konuştukları tüm dillerin toplumsal sözleşme ile

47 Ebû Mansûr el-Mâtürîdî, Kitâbü't-Tevhîd, thk. Fethullah Huleyf (Beyrut: Dârü'l-Meşrik, 1980), 99, 114, 125, 315.

48 Mâtürîlî, Kitâbü't-Tevhîd, 180.

49 Nesefí, Tabsıratü'l-edille, $1 / 474$.

50 Bâkıllânî, et-Takrîb ve'l-irşâd, 1/319-321.

51 Geniş bilgi için bk. Bâkıllânî, et-Takrîb ve'l-irşâd, 1/319-324.

52 Sa'düddîn Mesu'd b. Ömer et-Teftâzânî, Şerhü'l-Makāsıd, thk. Abdurrahmân Umeyr (Kum: yy, 1371), 1/61-63

53 Ali b. Ahmed İbn Hazm, el-Fasl fi'l-ehvâ ve'I-milel ve'n-nihal, (Beyrut: Dârü'l-Ma'rife, 1975), 1/31; 2/126.

54 Râzî, Mefâtihül'-gayb, 2/175; 550; Fahreddîn Râzî, el-Mahsûl, thk. Tâhâ Câbîr (Beyrut: Müessesetü'r-Risâle, 1997), $1 / 58,63-64$.

55 el-Bakara $2 / 31$.

56 Kitâb-ı Mukaddes, Yaratılış 02/19-20.

57 Râzî, Mefâtihü'l-gayb, 2/396. 
oluştuğunu kabul etmiştir. ${ }^{58}$ Daha sonra bu görüş pek çok Mu'tezilî tarafından savunulmuştur. ${ }^{59}$ Mu'tezilenin savunduğu ıstılâhîlik teorisinin insanın iradesi ve halku'l-Kur'ân'la da irtibatı vardır. ${ }^{60}$

Ehl-i Sünnetin sadece tevkîfilliği; Mu'tezilenin de sadece ıstılâhîliği savunduğunu düşünmek indirgemeci bir değerlendirme olacaktır. Pek çok Ehl-i Sünnetten ilim adamı, ıstılâhîliği reddetmediği gibi Mu'tezilîler de tamamen tevkîfîliği reddetmemektedirler. Nitekim Mu'tezilenin Hz. Âdem'e isimlerin öğretilmesini mucize olarak kabul etmesi ilk dilin tevkîfî olduğu anlamına gelmektedir.61 Kaynaklarda ayrıca genel kabulün aksine Mu'tezileden de bir grubun tevkîfîliği savunduğu bilgisi yer almaktadır. ${ }^{62}$

\subsection{Felsefecilere Göre Hz. Âdem'e Öğretilen İsimler}

Fârâbî (ö. 339/950) dil konusunda meleke teorisini benimsemiştir. Tevkîfîlik ve ıstlâhîlîkten farklı olarak meleke teorisi, insandaki dil kabiliyeti ile dil potansiyeline işaret eder. Bu teori belli ölçüde müfessirler tarafından da savunulmuştur. ${ }^{63}$ Meleke teorisine göre insanlarda diğer varlıklardan farklı olarak potansiyel bir dil kapasitesi vardır. İnsanlar bu potansiyeli kullanarak önce dilin harfleri ile seslerini oluşturur. Harfler ve seslerin birleşmesinden sonra lafızlar meydana gelir. Insanlar tarihin bilinmeyen bir zamanında varlıkları tanımlamak için birtakım ses ve lafızlar kullanmışlardır; o lafızlar diğer insanlar tarafından tekrar edilerek bazı varlıkların adları olmuştur. Bu önce birkaç kişiyle başlamış; sema/iş̧itme yolu ve nüfusun artışılla birlikte pek çok insanla paylaşılmaya devam etmiştir. Daha sonra akrabaların ve kabilenin geneline yayılan bu lafızlar; uluslaşmayla beraber bir milletin dili haline gelmiştir. Milletin dili, büyüklüğün bir sonucu olarak ağız, şive ve lehçe gibi diyalektiklere ayrılmıştır. ${ }^{64}$ Fârâbî'ye göre diller oluşurken önce güneş, ay, gök, yıldız ve yer gibi daha dikkat çekici varlıkların adları; sonra diğer varlıkların adları ortaya çıkmıştır. Zira âyette belirtildiği üzere varlıktan haber verme işi isimlerle başlamıştır. İş, eylem ve oluşlar da isimler arasında bağlantı kurmuş ve fiiller ortaya çıkmıştır. Fiilleri; sanatsal ve ahlâkî melekeler, bunları mantıkî çıkarım ve akıl yürütmeler takip etmiştir. Mantıkî çıkarım ve akıl yürütmeler de yeni bilgilere ulaşmayı sağlamıştır. Böylece ilim ve teknolojide (âletler ve pratik sanatlarda) ilerleme sağlanmış; her ilerleme yeni isim ve kavramlar ortaya çıkarmıştır. Bu nedenle dil, sürekli bir gelişme ve değişme göstermektedir. ${ }^{65}$ Fârâbî'nin bu görüşleri insanın yetenek ve potansiyeline işaret etmektedir. İnsanda yetenek ve potansiyel elbette vardır. Önemli olan bu yetenek ve potansiyelin üzerine ilk dilin inşasıdır. Hz. Âdem

58 İbn Teymiyye, Kitâbü'l-Îmân, 75-76.

59 Ebü'l-Hasen Kādî Abdülcebbâr, el-Muğnî fi ebvâbî tevhîd ve'l-adl, thk. İbrâhim Ebyarî (Kahire: Dârü'l-Mısriyye, 1958), 7/101; Râzî, Mefâtihü'l-gayb, 2/396; Süyûtî, el-Müzhir, 1/24.

60 Kādî Abdülcebbâr, Tenzîhü'l-Kur'ân ani'l-metâin (Beyrut: Dâru'n-Nahde, ts.), 21-22.

61 Ebü'l-Hasen Alî b. Muhammed b. Habîb el-Basrî el-Mâverdî, Edebü'd-dîn ve'd-dünya (Dimeşk: Dârü'l-ibni'l-Kesîr, 2008), 92.

62 Kādî Abdülcebbâr, el-Muğnî, 7/101.

63 Taberî, Câmiü'l-beyân, 1/252.

64 Fârâbî, Harfler Kitabı, 76; İsa Güceyüz, Temel belâgat terimlerinin teşekkülü: fesahat, belâgat, meânî, beyân ve bedî̀ (Erzurum: Atatürk Üniversitesi, Sosyal Bilimler Enstitüsü, Doktora Tezi, 2020), 11.

65 Fârâbî, Harfler Kitabı, 76; Ernst Von Aster, Bilgi Teorisi ve Mantık, çev. Macit Gökberk (İstanbul: Mehmet Sadık Kağıtçı Matbaası, 1945), 25. 
de Yüce Allah'tan vahiy aldığına ve Rab'le iletişim kurduğuna göre onun bir dili olmalıdır. Bu dil, âyetlerden anlaşıldığına göre tevkîfî olarak öğretilmiştir. ${ }^{66}$

İbn Haldûn (ö. 808/1406) da meleke teorisine yakın görüşler ortaya koymuştur. ${ }^{67}$ İbn Haldûn, dili; düşünce etrafında ve insilâh kavramıyla açıklamaya çalışmıştır. Ona göre Yüce Allah'ın insana öğrettiği bir kök dil vardır ve insanlar da uzlaşı sonucu bu kök dilden diğer dilleri oluşturmuştur. İnsanoğlunun maddî ve manevî pek çok özelliği vardır. Özellikle manevî yönü onun yaratıcı yönünü oluşturmaktadır. ${ }^{68}$ İnsanın bu manevî yönünde bil'l-kuvve ve bi'l-fiil'den oluşan melekiyet özelliği vardır. ${ }^{69}$ İnsanı diğer canlılardan farklı kılan özellik, onun beşerî yönünden ziyade insanî ve melekî yönüdür. ${ }^{70}$ İnsanın manevî yönünde bulunan "nefs-i natıka bi'l-kuvve"; duyuların nesneleri algılaması, kavraması ve akılla yorumlanmasıyla bi'l-fiil haline dönüşmekte; idrak, akıl ve düşünme aşamalarından sonra konuşma ortaya çıkmaktadır." ${ }^{\prime 71}$ İbn Haldûn'a göre insandaki dil melekesi süreç isteyen bir özelliktir. ${ }^{72}$ Toplumlar yaşadıkları coğrafyaya ve ihtiyaçlarına göre farklı kelimeler türetmiş ve diller oluşmuştur. ${ }^{73}$ Râzî ve İsferâyînî (ö. 418/1027) gibi âlimlerin değerlendirmelerine bakıldığında, bunların da meleke teorisi üzerinde durduğu ve görüşlerini daha çok tevkîfî-ıstılâhî birlikteliğiyle açıkladığı söylenebilir. ${ }^{74}$

Modern bilimler içerisinde Chomsky'nin potansiyel dil teorisi de meleke yaklaşımına benzemektedir. Potansiyel teoriye göre dilin temel gramer kuralları bütün insanlar tarafından ortak olarak kullanılmaktadır. ${ }^{75}$ Insanlarda yaratılıştan gelen bir dil yetisi vardır. İnsanlar dil yetisi konusunda aynı veya benzer fıtrî özelliklere sahiptir; değişen ise sadece kelime ve sembollerdir. Chomsky'nin bu açıklamaları Fârâbî ve İbn Haldûn'un meleke teorisini akla getirmektedir. Dolayısıyla potansiyel dil teorisi aslında Chomsky'den önce meleke yaklaşımı adı altında Fârâbî ve İbn Haldûn tarafından hatta kelamcılar tarafından oluşturulmuştur.

\section{Modern Bilimlerde Dil}

Modern bilimler doğa ve toplum bilimleriyle temayüz etmiştir. Toplum bilimleri; insanı, tarihi ve toplumu inceleyen bilimlerin genel adıdır. Dilin kökeni ve yapısı konusunda birey ve toplumu inceleyen modern bilimler de toplum bilimleri kapsamına girmektedir. Batı'daki felsefi gelenekler ve bilimsel yöntemler toplum bilimlerini farklı şekillerde adlandırmışlardır. Örneğin pozitif gelenek, toplum bilimlerini, sosyal bilimler; hermenötik tin bilimleri, yeni Kantçılık kültür bilimleri;

66 Âyetler için bk. el-Bakara, 2/31; Âl-i İmrân 3/45; en-Nisâ 4/171; er-Rûm 30/22; el-Beled 90/9.

67 Muhammed b. Muhammed b. Hasen el-Hadramî el-Mağribî ỉbn Haldûn, Mukaddime, çev. Süleyman Uludağ (İstanbul: Dergâh Yayınları, 2009), 2/851.

68 İbn Haldûn, Mukaddime, 2/286, 289, 773, 889.

69 İbn Haldûn, Mukaddime, 2/1014.

70 İbn Haldûn, Mukaddime, 2/1014.

71 İbn Haldûn, Mukaddime, 2/461, 1/300.

72 İbn Haldûn, Mukaddime, 2/1003.

73 İbn Haldûn, Mukaddime, 2/851.

74 Süyûtî, el-Müzhir, $1 / 21$.

75 Aktaran. John C. Condon, Kelimelerin Büyülü Dünyası: Anlambilim ve Illetişim, çev. Murat Çiftkaya (İstanbul: İnsan Yayınları, 2000), 43. 
Marksist gelenek ise tarih bilimleri olarak adlandırmıştır. ${ }^{76}$ Dolayısıyla bu çalışmada toplum bilimleri tabiriyle bireyi ve toplumu çeşitli boyutlarıla inceleyen bilimler kastedilmiştir. Bunun yanında toplum bilimlerinin bir parçası olan psikanaliz ve semiyoloji gibi bilimlerin de dil yaklaşımlarına değinilmiştir.

Platon ve Aristotales gibi filozoflar dilin toplumsal sözleşmeyle kurulduğunu savunmuşlar; dilin gündelik hayatta ve siyasette kullanımı üzerinde durmuşlardır. Heraklaitos ise Sünnî kelamcılarla müfessirler gibi dilin tevkîfî olduğunu kabul etmiş̧tir. Sofistler ise dili bir sistem olarak görmüşler; dil ve dilbilimsel konularla ilgilenmişler, dili, nesnelerin doğasını açıklamak ve betimlemekten ziyade insanların duygularına hitap etmek ve onları yönlendirmek için kullanmışlardır. Demokritos dili, insanın iç dünyasındaki seslerin somutlaşmış hali olarak açıklamış ve ıstılâhîliği savunmuştur. Buna göre dil; insanın bilinçsiz sesler çıkarımı ve anlatımı iken daha sonra anlam kazanmıştır. Bu görüş Darwin'in teorisinin temelini oluşturmuş; dilin gelişimi konusunda belli varsayımlar yapmış ancak o, insanlarda ve hayvanlarda bulunan dilin duygusal kısmını açıklayamamıştır. Bazı bilim adamları dilin çığlık benzeri seslerden oluştuğunu iddia ederken bazıları da öznelin dışsallaştırılmasıyla oluşan nesnelleşme olduğunu söylemişlerdir. ${ }^{77}$

Platon, tevkîfiliği eleştirmiş; böyle bir iddianın dillere kutsallık ve üstünlük sağlama çabasından kaynaklandığını söylemiştir. ${ }^{78}$ İbn Teymiyye (ö. 728/1328) ise bu iddialara karşı çıkarak Allah'ın kâinatı altı günde yarattıktan sonra arşına çekildiğini ve bu evrede Arapça gibi dilleri oluşturduğunu söylemiştir. Innsan yaratıldıktan sonra da bu diller; Hz. Âdem'e ve ilk insanlara öğretilmiştir. ${ }^{79}$ Bu nedenle İbn Teymiyye, ilâhî olması sebebiyle Arapçanın diğer dillerden daha üstün olduğunu belirtmiş; ancak diğer diller ıstılâhî olsa bile onların da önemli olduğunu vurgulamıştır. Zira ona göre diller birbirine benzediği için ortak bir özelliğe sahiptir. Şekil olarak dillerin ortak bir mevzuatı/grameri olmasa da insanların dil konuşması ve bu kabiliyete sahip olmaları dilin kökeninin tevkîfî olduğuna işaret etmektedir. ${ }^{80}$ Modern dönemde ise Batılılardan Jacques Ellul (ö. 1994) Müslüman âlimler gibi köken dil konularına değinmiş; Yüce Allah'ın Hz. Âdem'e isimleri öğretmesini, insanın diğer varlıklar karşısındaki üstün konumuyla açıklamıştır. ${ }^{81}$ Zira insan, diğer varlıklarla karşılaştırıldığında onlardan oldukça farklıdır. Dolayısıyla ta'lîmü'l-esmâ, insanın üstün konumunun yanı sıra Yüce Allah'la Hz. Âdem arasındaki Rab-kul ilişkisine de işaret etmektedir. ${ }^{82}$

Modern toplum bilimlerine bakıldığında ise genel olarak kök dilden ziyade dilin toplumsal yaşamdaki işlevine bakılmış ve dil tahlilleri bu bakış açısıyla yapılmıştır. Hatta Saussure dilin kökeni üzerinde durmanın anlamsız olduğunu söyle-

\footnotetext{
Özlem, Bilim Felsefesi, 106.

Zıllıoğlu, Illetişim Nedir?., 123.

Platon, "Cratylus" Complete Works: Dijital Edition, 384a, 387c-d, 435d-e.

İbn Teymiyye, Kitâbü'l-Îmân, 79.

İbn Teymiyye, Kitâbü'l-Îmân, 80.

Jacques Ellul, Sözün Düşüşü, çev. Hüsamettin Aslan (İstanbul: Egin Yayınları, 2012),84.

Ellul, Sözün Düşüşü, 65.
} 
miştir. ${ }^{83} \mathrm{Hal}$ böyle olmakla beraber modern bilim insanlarının dili kutsar derecede önemsemeleri ve dili tüm toplumsal kurumların temeli olarak görmeleri, İslâm'ın ilk dönemlerinden buyana Hz. Âdem'e öğretilen isimleri dil ve dil yetisi olarak açıklayan İslâm âlimlerinin açıklamalarını desteklemektedir. Her ne kadar toplumbilimciler köken dile girmeseler de onların dili insanî özelliklerin en önemlisi olarak açıklamaları, Hz. Âdem'e secde eden meleklerin neye saygı duyduklarını açığa çıkarmaktadır.

Toplum bilimleri içerisinde sosyolojinin ayrı bir yeri vardır. Sosyolojinin kurucusu kabul edilen Durkheim (ö. 1917) çalışmalarında dile ayrı bir önem vermiştir. Onu diğer sosyoloji bilginleri takip etmiştir. Hatta sosyologlar ve psikologlar dili toplumsal kurumlar içerisinde ilk sıraya almışlardır. Sosyoloji içerisinde sembolik etkileşimcilik, yapısalcılık, fenomenoloji ve postyapısalcılık gibi farklı yaklaşımların dile ve sembollere önem verdiği görülür.

Durkheim, ilk dile ve isimlere dair görüş belirtmemiştir. $\mathrm{O}$, dinî verilerin tamamen inkâr edildiği pozitif bilim anlayışına bağlı kalarak sadece dil-toplum ilişkisi ve dili bireylerin değil toplumun oluşturduğu tezine dair görüşlere sahip olmuştur. Ona göre bu durumda dil ortaya koymak tek bir ferdin işi olmayıp toplumlar tarafından oluşturulmuştur. Bu görüşüyle o, ıstılâhî/uzlaşmacı görüş içerisinde yer almıştır.

Durkheim, sosyolojinin kurallarını belirlerken toplumun olgulardan oluştuğunu ve bu olgular içerisinde dilin önemli olduğunu belirtmiştir. Ona göre dil, sosyal bir olgudur ve ampirik olarak da incelenmeye müsaittir. İlk olarak dil; istisnaları olsa da gramer, kelime, telaffuz, hece ve harf gibi somut özelliklerden oluşmaktadır. Bu nedenle dilin somut ve soyut özellikleri mantıkî ve felsefî bir açıklamadan ziyade ampirik olarak incelenmelidir. İkinci olarak dil; bireylerin dışında ve haricinde toplumsal bir fenomen olarak yer almaktadır. Dil; birey tarafından kullanılsa da dillerin oluşturulması ve yaratılması bireyleri aşmaktadır. Dil; doğa yasaları gibi bir yasa özelliği taşımaktadır. Dil topluma ait olup bireylerin ötesindedir. Üçüncü olarak dil; insanları kuşatmakta ve onları belli davranış ve kalıplara sokmaktadır. İletişim halindeki insanların birbirini nasıl adlandıracağı ve birbirlerine nasıl davranacağını dil belirlemektedir. Dördüncü olarak dilde bir değişme kabul edilecekse bu toplum tarafından gerçekleştirilecektir. ${ }^{84}$

Durkheim, dille alakalı olarak temsiller ve semboller üzerinde de durmuş; temsiller ve sembollerin kolektif temsil veya kolektif bilinci oluşturduğunu ileri sürmüştür. Ona göre, başta dinî semboller olmak üzere mitoloji ve popüler efsaneler de toplumsal temsilleri oluşturmakta ve toplumun kolektif bilinci somutlaştırmaktadır. ${ }^{85}$

Psikologlardan Freud (ö. 1939) da psikanalizinde dil üzerinde durmuş; ego ve bilinçdışı gibi yapısal fenomenlerin insanların içerisinde yetiştikleri dille oluştuğunu ve dil sayesinde baskı altında tutulduğunu belirtmiştir. Bu baskı, insanların

83 Ferdinand de Saussure, Genel Dil Bilim Dersleri, çev. Berke Vardar (Ankara: Birey ve Toplum Yayınları, 1985), 117.

84 George Ritzer, Sosyoloji Kuramları, çev. Himmet Hülür (Ankara: Deki Yayınları 2014), 78.

85 Emile Durkheim, The Rules of Sociological Method (New York: Free Press, 1982), 40. 
doğal hareket etmelerini ve yeterince özgür olmalarını engellemektedir. Dille engellenen insanlar, arzularını sürekli olarak bilinçdışına itmektedirler. Bilinçdışına itilen bu istekler yine dil, dil sürçmesi (lapsus) ve bazı davranışlarla ortaya çıkmaktadır. Bazen bu istekler o kadar bastırılır ve bilinçdışına itilir ki rüyalarla ve nevrozlarla kendini sembolik olarak gösterir. ${ }^{86}$

Psikanalizini dil üzerine kuran Freud, özellikle dil vasıtasıyla bilinçdışına itilen arzuları yine dille çözmeye çalışmıştır. O, bunu gerçekleştirmek için serbest çağrışım tekniğini geliştirmiştir. Serbest çağrışım tekniği, bireyin düşündüğü ve hissettiği her şeyi açık bir şekilde hekimine açıklamasıdır. ${ }^{87}$ Freud'a göre, hastayı anlamak, tanımak ve onu tedavi edebilmek için serbest çağrışım tekniğinin kullanılması gerekir. Ancak bu şekilde hasta ve hastalığının nedenleri daha iyi anlaşılmış olur. Freud'a göre insanların ketumluğunun ve konuşmalarına dikkat etmelerinin sebebi toplumsal olarak dille inşa edilmektedir. Zira toplum tarafından kötü görülen bencillik, gaddarlık ve cinsellik gibi duygular bilinçdışına itilmektedir. ${ }^{88}$ Bilinç dışına itilen bu duygular, insan davranışlarını belirlemektedir; bilinçdışı süreçleri de biyolojik etkenler ile kültür oluşturmaktadır. Bilinçdışı dilin yanı sıra düşünce ve rüyalarda da kendini simgesel olarak göstermektedir. Bilinç, bilinçdışı ve bilinçaltı anlamları başta olmak üzere tüm anlamlar kişinin öznel ve ailevî konumuna göre dille düzenlenir. ${ }^{89}$ Freud, dilin bilinç ve bilinçdışına şekil vermesi konusunda Saussure'den bir hayli etkilenmiştir. Dil o kadar önemlidir ki kendi içinde anlam barındıran simgeler ve rüyalar bile dille daha net olarak açıklanır ve tabir edilir. Rüyalar dil gibi bir kesinlik ifade etmeseler de açıklama ve tabir etmeyi hak eden formlara sahiptir.

Freud'un teorisini farklı bir bakış açısıyla okuyan Lacan (ö. 1981) da bilinç, ego ve oedipal söylem (karşı cins ebeveyni sahiplenme ve hemcins ebeveyni saf dışı etme düşüncesi) ile bilinçdışı kavramlarını yeniden yorumlamış ve dile çok önem atfetmiştir. ${ }^{90}$ Psikanalizci Lacan'a göre de bilinçdışı, dil içinde ve dilin aracı olarak ortaya çıkmaktadır. ${ }^{11}$ Psikanalizin nesnesi bilinç; dilin mantıkî bir sonucudur. ${ }^{92}$ Zira her türlü düşünce dil tarafından oluşturulmaktadır. ${ }^{93}$ Psikanaliz bir dil analizi olup ulaşmak istediği sonuçlar da anlam ve yapısal bir belirlenimlerdir. ${ }^{94}$ Freud ve Lacan'ın dille ilgili görüşlerine bakıldığında, dil-benlik ve dil-kişilik üzerinde durdukları görülür. Onlar çalışmalarında İslâm âlimleri gibi dilin mahiyeti ve kökeni gibi konulara girmemişler; dili, insanı tanıma ve tedavide bir araç olarak kullanmışlardır. Onların dile bu kadar odaklanmaları, insanı dille tanımlamaları ve çözümlemeleri, isimlerden haber veren $\mathrm{Hz}$. Âdem'i dille tanıyan meleklere benzemektedir. Nasıl ki melekler insanı dille tanımışlarsa psikologlar da insanı yine dille tanımaktadırlar. Bu da Hz. Âdem'e öğretilen isimlerin dil olduğunu ve insa-

\footnotetext{
86 Saffet Murat Tura, Freud'dan Lacan'a Psikanaliz (İstanbul: Ayrıntı Yayınları, 1996), 40.

87 Sigmund Freud, Yaşamım ve Psikanaliz (İstanbul: Say Yayınları, 1997), 262.

88 Freud, Yaşamım ve Psikanaliz, 263.

89 Rosalind Coward ve John Ellis, Dil ve Maddecilik, çev. Esen Tarım (İstanbul: Iletişsim Yayınları, 1985), 20, 21.

90 Tura, Freud'dan Lacan'a Psikanaliz, 99.

91 Jacques Lacan, My Teaching (Ingiltere: Verso Press, 2008), 26.

92 Tura, Freud'dan Lacan'a Psikanaliz, 112.

93 Lacan, My teaching, 107

94 Lacan, My teaching, 26; Tura, Freud'dan Lacan'a Psikanaliz, 115.
} 
nın varlıklar içerisindeki üstün konumunun dille ve açıklamayla ortaya çıktığını göstermektedir.

Sosyologlar modern ve postmodern bilim anlayışına göre hareket ettikleri için dile ta'lîmü'l-esmâ âyeti bağlamında ve İslâm âlimleri gibi yaratılış teorisine göre yaklaşmamışlardır. Dolayısıyla sosyologlar köken dil hakkındaki bir görüş belirtmek yerine dil-toplum ilişkisine yer vermişlerdir. Ancak onların dil-toplum ilişkisine yer vermeleri; Hz. Âdem'e öğretilen isimlerin seküler açıdan da dil olduğunun teyidi anlamına gelmektedir. Zira âyette insanın diğer varlıklara üstünlüğü isimlerden haber vermekle ve dille tezahür etmiştir.

Toplum bilimcilere göre benlik ve kültür dille ve iletişimle oluşmaktadır. Benlik, şahsî bir "ben" ile toplumsal bir "bana"nın etkileşim ve birleşiminden öznel ve nesnel olarak oluşmaktadır. Benlik gündelik hayat içerisinde toplumsallaşma ile gerçekleşir ve bu toplumsallaşma sürekli kendini yenileyerek devam eder. Mead (ö. 1931) bu hakikati "benlik tipolojisi"; Berger (ö. 2017) ve Luckmann (2016) "hakikatin öznel ve nesnel yönleri"; bazıları da kişilerin içerisinde yer aldıkları "yapılaştırıcı mekanizma" olarak açıklamışlardır. Toplum bilimci Berger ve Luckmann Gerçekliğin Toplumsal İnşası adlı kuramlarını dil ve iletişime dayandırmışlardır. ${ }^{95}$ Onlar, gündelik hayatta kullanılan dilin bireyler arasında somut bir alan oluşturduğunu, sürekli nesnelleştirmeler sağladığını ve bu nesnelleştirmelerle de gündelik yaşamda bir düzenin oluştuğunu belirtmektedirler. ${ }^{96}$ Bourdieu (2002) da "habitus" kavramını çok boyutlu değerlendirerek bireyleri benlik bileşenleriyle içeriden harekete geçiren yapılaştırıcı bir mekanizma olarak tanımlamıştır. ${ }^{97}$ Markova da ben ve ötekiler ilişkisini açıklarken dil ve iletişim olgusu üzerinde durmuştur. İletişim olgusuna göre insan zihninin varlığı; düşünme ve konuşma halinde kendini göstermektedir. ${ }^{98}$

Bir başka toplum bilimci Geertz (ö. 2006) de dil ve toplum arasındaki ilişkiye dikkat çekmiş; kültürün oluşmasında dil, iletişim ve delâletlerin vaz geçilmez bir önemi olduğunu belirtmiştir. ${ }^{99}$ Buna göre bireyler arasında dil, etkileşim ve göstergeler olmadan karşılıklı anlaşma mümkün değildir. Filozof Gadamer'e (ö. 2002) göre ise dil çok önemlidir; insanlar arasında ufuklar kaynaşması ve bireyler arası ortak zemin oluşturarak iletişimi sağlar. Dille alakalı olarak Eriksen ise analog kavramsallaştırmasını kullanmış; bireylerin öznel gerçekliklerinin, gerçeklik döngüsüyle kazanıldığını belirtmiştir. Zira gerçeklik döngüsü, dil sayesinde yani formlardan anlamlara ve anlamlardan formlara doğru gerçekleşmekte-

95 Markova, "Doğunun ve Batının Yerelliği", Sosyal Temsiller ve Demokrasi, ed. Sibel Ayşen Arkonaç (İstanbul: Alfa Yayınları, 2004), 127. 121-159.

96 Peter Berger ve Thomas Luckmann, Gerçekliğin Sosyal Inşası: Bir Bilgi Sosyolojisi Incelemesi, çev. Vefa Saygın Öğütle (İstanbul: Paradigma Yayıncılık, 2008), 34.

97 Ümit Tatlıcan ve Güney Çeğin, Bourdieu ve Giddens: Habitus veya Yapının Ikiliği, der: Güney Çeğin, vd., (İstanbul: Iletişim Yayınları, 2007), 315. 303-366.

98 Markova, "Doğunun ve Batının Yerelliği", 129.

99 Clifford Geertz, Kültürlerin Yorumlanması, çev. Hakan Gür (Ankara: Dost Kitabevi yayınları, 2010$), 19$. 
dir. ${ }^{100}$ Eriksen'in analog kavramlaştırmasında bağlamsal ve yorumsal olan, tek bir modelde toplanamaz. Benlik; dil ve iletişim sayesinde şahsî bir "ben" ile ictimâî bir "bana"nın birleşiminden öznel ve nesnel olarak oluşur. Benlik gündelik yaşam içerisinde toplumsallaşma ve yeniden toplumsallaşmayla beraber kendini gerçekleştirir. Bunu bir şema halinde şöyle gösterebiliriz:

\begin{tabular}{|c|c|}
\hline $\begin{array}{c}\text { EPISTEMOLOJi } \\
\text { ZiHIN } \\
\begin{array}{c}\text { BiREYSELLŞMiş } \\
\text { BENLiK (EGO) }\end{array} \\
\text { Öznel Gerçeklik } \\
\begin{array}{c}\text { SOSYAL BENLiK } \\
\text { (EGO) }\end{array}\end{array}$ & 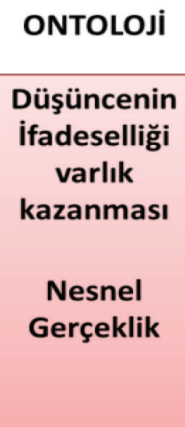 \\
\hline
\end{tabular}

\subsection{Sembolik Etkileşimcilik ve Dil}

Toplumsal kuramlardan olan sembolik etkileşimcilik adından da anlaşılacağı üzere dil ve sembollere öncelik vermiş; benliğin dil ve etkileşimle oluştuğunu belirtmiştir. Bu yaklaşım içerisinde Cooley (ö. 1929) insanlar arası iletişim sonucu oluşan ayna benlik kavramını geliştirmiştir. Mead (ö. 1931) Cooley'in ayna benliğini geliştirmiş ve benliğin toplumsal etkileşimle oluştuğunu belirtmiştir. Etkileşimin en önemli unsuru sembollerdir ki simge, dil ve anlamlardan oluşmaktadır. ${ }^{101}$ Semboller başta konuşma dili olmak üzere beden dili, gösterge ve işaretler olup anlamların formları ve kalıplarıdır. ${ }^{102}$ Semboller varlıkların açıklayıcıları ve tanımlayıcılarıdır. Örneğin "masa" sözcüğü kendisi bir sembol iken manası dört ayaklı bir nesneye tekabül etmektedir. ${ }^{103}$ Dil ve sembollerin nesnelerle doğrudan alakası olmayıp insanlar arası uzlaşı sonucu ortaya çıkmıştır. Sözcük ile eşya arasında ilişski olsa idi dünyada sadece bir tane dilin olması gerekirdi. Her toplum varlıkları karşılamak için kendine göre bir dil ve sembol geliştirmiş̧tir. Diğer varlıkların içgüdüsel etkileşimlerine mukabil; insanlar sembol ve dilden oluşan ortak bir anlam alanı inşa etmişlerdir. ${ }^{104}$

100 Thomas Hylland Eriksen, Kültür Terörizmi: Kültürel Arınma Üzerine Bir Deneme, çev. Önder Otçu (Diyarbakır: Avesta Yayıncılık, 2000), 84.

101 Margeret M. Poloma, Çağdaş Sosyoloji Kuramları, çev. Hayriye Erbaş (Ankara: Gündoğan Yayınları, 1993), 224.

102 Poloma, Çağdaş Sosyoloji Kuramları, 224, 225.

103 Michael Haralambos ve Martin Holborn, Sociology: Themes and Perspectives (London: Harper Collins, 1995) 891.

104 Haralambos ve Holborn, Sociology, 891. 


\subsubsection{George Herbert Mead'da Dil}

Sembolik etkileşimde dil ve sembol çok önemlidir. İnsanın bir nevi kimliği olan benlik ile içinde yaşadığı toplum ve kültür de dil ve sembollerle oluşur. Bu nedenle Mead'a göre toplum, bir yandan benlik ve zihnin üreticisi iken diğer yandan da benlik ve zihnin bir ürünüdür. Bireyin zihnî gelişimi ile benliğinin oluşumunu toplum sağlarken toplum da bireylerin ortak zihin ve benliklerinden meydana gelmektedir. Benlik ve zihin bir yandan toplumsal yapının öznesi iken diğer yandan da nesnesidir. ${ }^{105}$ Birinci olarak benlik zihinle bilinçli olmakta; zihin sayesinde şart ve durumlara göre hareket etmekte mazi, hal ve müstakbelle bağlantı kurabilmektedir. İkinci olarak benlik; dil ve semboller aracılığı ile toplumun diğer fertleriyle iletişim kurabilmektedir. Zihin; bireyin kendini, başkalarını anlama ve yorumlama potansiyeli iken özbilinç ise bireyin kendi ve başkalarının farkında olmasıdır. ${ }^{106}$

Sembolik etkileşimcilik simgeler içerisinde özellikle dil ve jestlere ayrı bir önem atfeder. Zira toplumsal etkileşimin temeli dil ve jestlerdir. Dil ve jest arasında bir tercih yapıldığında ise dilin jeste karşı önceliği vardır. Selefleri gibi ilk dil veya köken dil konularına girmeyen Mead, tarihin her döneminde bireylerin ve toplumun oluşturduğu dil üzerinde durmuştur. Böylece o, uzlaşıyı/ıstılâhî teoriyi kabul etmiş olmaktadır. Dil; bireyler tarafından oluşturulmakta, toplumsallaştıktan sonra da bireyleri etkisi altına almaktadır. Bireyler bir yandan dilin yaratıcısı iken diğer yandan da dilin nesnesidir. ${ }^{107}$

Sembolik etkileşimciliğe göre jestler; dil gibi seslere ve lafızlara sahip değildir; bunlar toplumda sosyalleşme aracılığı ile öğrenilen yüz ifadeleri, belli hal, davranış ve hareketlerdir. Jest bazen tek başına bazen de dille beraber iletişim vazifesi görür. Eğer jestleri lafızlar takip ederse iletişim daha açık ve daha objektif hale gelmektedir. Jestler İslâm âlimleri tarafından da ele alınmış ve vazî lafzî olmayan delâlet olarak adlandırılmıştır. Fârâbî ve İbn Sînâ gibi filozof ve mantıkçılar vaz'î delâletteki sembolleri aklî ve doğal görmemişler; bunların örf, eğitim ve kültürle öğrenildiğini belirtmişlerdir. İnsanların iletişimini sağlayan lafzî delâletler beşer ürünüdür. Zira bunlar varlığın farklı isimlendirmesi olduğu için kültürden kültüre farklılık gösterir. Bunların kültürel etkileşim sonucu evrensel olanları da olabilir. Fârâbî ve İbn Sînâ, mantık ilminde pek çok delâletle ilgilenseler de özellikle dil anlamına gelen lafzî delâlet üzerinde durmuşlardır. Zira jest ve beden dili belli ölçüde delâlet olsa da iletişimin ve mantığın asıl amacı doğru iletişim ve düşünmedir. Bu nedenle insanlar hal, hareket, eylem, jest ve mimikleriyle iletişim sağlasalar da lafzî delâlet/dil kadar kesinlik ifade etmez. Aynı şekilde lafzî olarak kabul edilen aklî ve doğal delâletler dil gibi kesinlik ifade etmedikleri için mantığın hari-

105 George Herbert Mead, Mind, Self and Society (Chicago: Chicago University Press, 1934), 1-7; Alan Swingewood, Sosyolojik Düşüncenin Kısa Tarihi, çev. Osman Akınhay (Ankara: Bilim ve Sanat Yayınlar 1998), 311.

106 Martin Slattery, Key Ideas in Sociology (London: Mcmillan, 1991) 192.

107 Bernard N. Meltzer; John W. Petras; Larry T. Reynolds, Symbolic Interactionism: Genesis, Varieties an Criticism (London: Routledge and Kegan Paul, 1975), 36. 
cinde tutulur. ${ }^{108}$ Sembolik etkileşimciler, köken dil problemine değinmemişler; benlik ve toplumsal etkileşimde dil, iletişim ve dilsel delâlet problemini ele almışlardır.

\subsubsection{Herbert Blumer'de Dil}

Mead'dan sonra sembolik etkileşimcilikte önemli bir düşünür olan Blumer (ö. 1987) de dile ve simgelere vurgu yapmıştır. Blumer'e göre, anlamların öznel boyutu; etkileşimle oluşması ve yorumla anlamların değişmesi gibi etkileşimciliğin üç temel ilkesi vardır. Sosyal hayatta insanlar anlamları önce bireysel olarak değerlendirirler; etkileşimle yeni anlamlar oluştururlar, en sonda bireyler bu anlamlar üzerinde yorum yaparak değişime uğratırlar. Anlamların bireysel değerlendirilmesi, anlamların öznel manası anlamına gelmektedir. Zira bireyler belli ölçüde toplum tarafından şekillense de onların fâil özelliği daha baskındır. Etkileşimle yeni anlamların oluşturulması, iletişimi sağlayan manaların beşer tarafından inşa edilmesi ve oluşturulması demektir. Makro teorilerin ifade ettiği gibi anlamlar önceden var olan bir yapı olarak tamamen bireyleri şekillendirmemekte aksine bireyler tarafından sürekli olarak geliştirilmekte ve değiştirilmektedir. Anlamların yorumla değişmesi ise bireylerin yetenek ve kapasitelerine göre toplumsal etkileşim sonucunda yeni manalara ulaşmasıdır. ${ }^{109}$

Anlamın oluşmasında nesneler, bireyler üzerinde etken değildir. Varlıklara ve olaylara anlam veren ve bunları isimlendirilen insanlardır. Bazı semâvî dinlerin yaratılış kıssasında Hz. Âdem ve Havva'yı yılanın kandırdığı ifade edilir. Kur'ân'a göre Hz. Âdem ve Havva'yı hataya düşüren yılan değil şeytandır. Dolayısıyla yılanla ilgili hikâyenin İslâmî bir temeli yoktur. Ancak israiliyyatta bu bilginin bulunduğu söylenebilir. Hal böyle iken diğer semâvî dinlerle birlikte Türk halkı için de yılan sevimsiz ve tehlikeli bir hayvan; aynı zamanda gizli bir düşmandır. Fakat semâvî dinlerdeki bu anlam tüm kültürler için geçerli olmayıp karşıt düşünceye sahip toplumlar da vardır. Bazı kültürlere göre yılan kötü bir canlı olarak görülmeyip eti bile yenilmektedir. Yine biyolog ve çevrecilere göre yılan doğal seleksiyonun en önemli üyesidir. Varlıklara verilen anlamlar zaman ve mekâna göre değiştiği gibi kültürden kültüre de değişmektedir. ${ }^{110}$

Anlamlar nesnelerden bir öz olmayıp insanlar arası etkileşimle inşa edilmektedir. Bu sebeple nesneler kendilerine atıf yapılan varlıklardır. ${ }^{111}$ Nesneler isimlendirme ve anlam olarak; fiziksel, toplumsal ve soyut olarak üçe ayrılır. Dolap, masa, sandalye gibi eşyalar fiziksel nesneleri; ana-baba, öğretmen, öğrenci gibi kelimeler toplumsal isimleri ve his, merak, duygu ve düşünce gibi kavramlar soyut varlıkları göstermektedir. Soyut varlıklara Allah, melek, cennet ve cehennem gibi metafizik alana ait isimleri de ilave edenler vardır. Bu üç tasnif içerisin-

108 Ebu Nasr Fârâbî, el-Elfâzu'l-musta'mele fi'l-mantık, thk. Muhsin Mehdi (Beyrut: Dâru'l-Meşrik, 1968), 41-43; İbn Sînâ, Kitâbu'l-işârât/Les Livres des directives et remarques. çev. A. M. Goichon (Paris/Beyrut: Librairie Philosophique J.Vrin 1951), 82.

109 Haralambos ve Holborn, Sociology, 894.

110 Herbert Blumer, Symbolic Interactionism: Perspective and Method. Englewood Cliffs (New Jersey: Prentice-Hall Inc,. 1969), 4-5; Poloma, Çağdaş Sosyoloji Kuramları, 225.

111 Poloma, Çağdaş Sosyoloji Kuramları, 229. 
de en somut olanı fiziksel nesneler olmasına rağmen bunların adlandırılması ve anlamlandırılmasında bile büyük farklılıklar vardır.

Sembolik etkileşimciliğe göre, toplumsallaşmayla ve dille beraber bireylerin zihninde bir dünya tasavvuru oluşmaktadır. İnsanların düşünen ve iradeli varlıklar olması sebebiyle de bu tasavvurlar sürekli değişmekte ve devamlı olarak kendisini yeniden üretmektedir. Buna bağlı olarak bu değişim ve yeniden üretimde toplumsal yaşamın inşa ettiği sembol, anlam ve dilin araştırılması gerekir. Semboller, diller ve anlamlar, insanları diğer canlılardan ayırmaktadır. Zira insanlar sembol, anlam ve dille etkileşim oluşturmaktadır. Bu nedenle birey-toplum ikiliği yerine toplum içindeki birey üzerinde durulmalıdır. ${ }^{112}$ Blumer'e göre toplum sürekliliği, akışı ve değişimiyle beraber incelenmelidir. Bu inceleme yapılırken insanî en önemli özellik olan dil, sembol ve anlamlara müracaat edilmeli ve toplumsal ilişkilerin nicelik ve niteliği ortaya konulmalıdır.

Sosyoloji kuramları içerisinde tüm yaklaşımlar dile önem vermiştir; ancak sembolik etkileşimcilik ile yapısalcılık, sembol ve dille özdeşleşmişlerdir. Sosyolojide Durkheim, işlevselciliğin olduğu kadar yapısalcılığın da ilk temsilcisi kabul edilebilir. Bununla birlikte dil anlamında yapısalcılığa Ferdinand de Saussure'nin ayrı bir katkısının olduğu aşikardır. O, Genel Dil Bilim Dersleri adlı çalışmasında semiyoloji üzerinde durmuş; ${ }^{113}$ semiyolojiyi işaretler ve işaret bilimi olarak adlandırmıştır. O, toplumsal yapıyı dil yapısına benzeterek kuramını açıklamıştır. İnsanlar nasıl bir dil sistemi içerisinde iletişimlerini sağlıyorlarsa aynı şekilde toplumsal bir sistem içerisinde de gündelik hayatlarını ve etkileşimlerini sağlamaktadırlar. Bu nedenle semiyolojiyi, dil ve diğer yönleriyle birbirinden ayırmıştır. Dil de semiyoloji içerisindedir fakat diğer işaret sistemlerinden farklıdır. Onun toplum ve dil sistemi benzetmesi dilbilimcileri ile sosyal yapısalcıları etkilemiş ve yapısalcılıkta yeni açılımlar sağlamıştır. Saussure çalışmalarında köken dil konusuna girmemiş; dilin kökeninin önemli olmadığını belirtmiş, toplumların kurucu ögesinin dil olduğu ve dilin işlevselliği üzerinde durmuştur. ${ }^{114}$ Buna göre o, dil konusunda ıstılâhîliği/toplumsal uzlaşıyı kabul etmiştir. ${ }^{115}$

\subsection{Yapısalcılıkta Dil}

Saussure, Genel Dil Bilim Dersleri adlı kitabında dil ve söz ayrımı yapar. Ona göre dil ve söz farklı şeylerdir. Dil; bir kültürün iletişimini sağlayan soyut gramer kuralları iken söz; dilin uygulamasının başladığı, iletişimin ve konuşmanın ortaya çıktığı somut bir haldir. Dil zamanla oluşmuş kolektif bir sistem iken söz; bireysel ve ilişkisel bir süreçtir, söz bir olay iken dil toplumsal bir olgudur. Saussure'ye göre söz; bireysel ve ilişkiseldir. Dil ise, bu sözlerin bireylerden çıkıp onları aşması ve toplumsal bir sisteme dönüşmesidir. ${ }^{116}$ Dilin toplumsal bir olgu olduğunu Durk-

\footnotetext{
112 Ken Plummer, Herbert Blummer Key Sociological Thinkers. (Der.) R. Stones (New York: Mcmillan, 2008). 110.

113 Semiyoloji, başta dil ve sembol olmak üzere tüm işaret sistemlerini inceleyen bir bilim dalıdır.

114 Saussure, Genel Dil Bilim Dersleri, 117.

115 Saussure, Genel Dil Bilim Dersleri, 112.

116 Saussure, Genel Dil Bilim Dersleri, 49-51.
} 
heim de söylemiştir. Zira toplumsal olgular, bireyler üstü bir yapıdır. Saussure de Durkheim gibi dilin konuşana, muhataba ve herhangi bir şeye indirgenmesini kabul etmemiştir. Dil toplumsal bir olgu olduğu için yasa niteliği taşımaktadır. Dil bir yandan bireylerin konuşmalarından bağımsız bir yapı oluştururken diğer yandan da sistemiyle bireyler üzerinde yapılandırıcı bir etkiye sahiptir. ${ }^{17}$ Bu özelliğiyle dil, o dili konuşan tüm bireyin konuşmasını ve iletişimini şekillendirmektedir. Dilin somut bir gerçekliği olmasa da insanların iletişim şekillerinden yola çıkarak dil yapısının analizlerini yapmak, belli kural ve kaideler çıkarmak mümkündür. Bu dil sistemi o kadar geniş̧tir ki başta konuşma olmak üzere tüm bireysel iletişimler onunla gerçekleşir. Buna göre gerçeklik sadece, dille oluşturulur. ${ }^{118}$ Dilin olaylardan/bireysel iletişimlerden oluşan bir yapı olduğunu bir şema halinde şöyle gösterebiliriz:



\subsubsection{Ferdinand de Saussure'de Dil}

Saussure'ye göre dil (langue), bireylerin konuşma ve iletişimlerini gerçekleştirdikleri bir yapı; kelimeleri, cümleleri, felsefeleri ve mantıklarını oluşturdukları soyut kurallar manzumesidir. Bu dil yapısının dilbilimciler tarafından derlenmiş haline gramer denilmektedir. Dil hem bireyler tarafından dışsallaştırılarak oluşturulmakta hem de dışsallaştırılan bu dil bireyleri kontrol altına almaktadır. Zira her doğan bir çocuk kendini daha önce ataları tarafından oluşturulmuş bir dilin kuralları içinde bulmakta ve bu dile göre iletişim kurmaktadır. Söz (parole) ise dilden biraz farklı olup bu dil sistemi içerisinde iletişimde bulunmaktır. Bu iletişimler belli bir süre pek çok insan tarafından paylaşılıp sisteme dahil olsa da öz itibariyle söz bireysel bir olaydır.

Saussure'ye göre dil; bireylerin üzerinde, bireylerin uzlaşıyla oluşturdukları toplumsal bir sistemdir. Günlük yaşam içerisinde kullanılan konuşma (söz/kelam) ise dil sistemi içerisinde gerçekleşen bir olaydır. Zira dille sözü ayıran nokta burasıdır ki dil bir olgu; söz ise bir olaydır ancak dil bu olaylardan oluşmakta-

117 Swingewood, Sosyolojik Düşüncenin Kısa Tarihi, 311.

118 Coward ve Ellis, Dil ve Maddecilik, 28. 
dır. Dilde kendine göre belli bir mantık ve sistem varken günlük iletişimde bu kuralların harfiyen uygulanması gerekmez. Çünkü insanlar, gündelik dilde iletişimlerini sağlarken dil kurallarından ziyade duygu aktarımını ön plana çıkarırlar. Bu nedenle bir dil sistemi içerisinde de olsa bireyler zaman, mekân ve durumlara göre değişen farklı bir iletişim usulü kullanırlar. İnsanlar için gramer kuralları ile iletişimi gerçekleştirmek önemlidir. Bu sebeple söz, bireylerin dili kullanma esnasında meydana gelen artzamanlı ancak somut bir olaydır. Dilin bir olgu, sözün ise bir olay olduğunu bir tabloda şöyle gösterebiliriz. Bu tablo dil sistemi ile söz ilişkisinin yanı sıra toplumsal olay-olguya da işaret etmektedir.

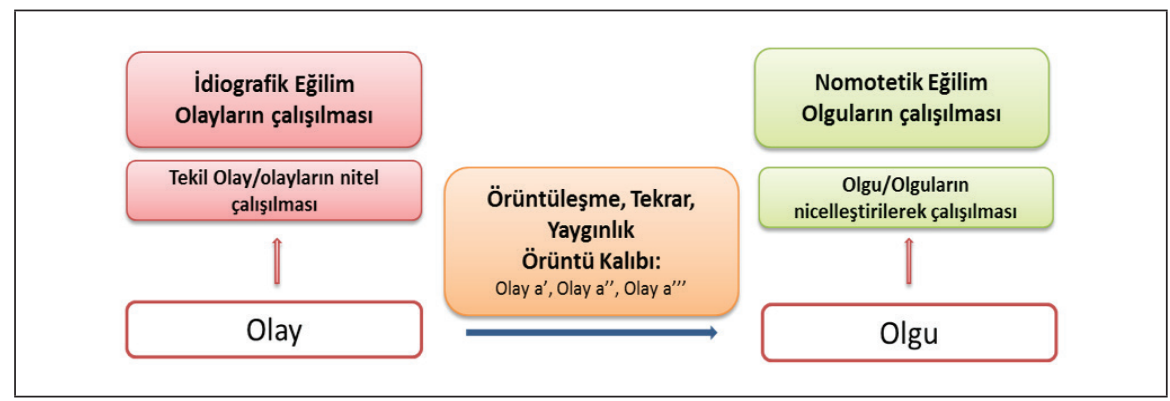

Saussure, dilin sürekliliği konusuna da değinmiş; dilin sürekliliğini senkron ve diyakron kavramsallaştırmasıyla açıklamıştır. O, dilin belli bir zaman, mekân ve bağlam içerisinde gerçekleşen evresini eşzamanlı (senkron) düzlem; zaman içerisindeki değişikliğini de artzamanlı (diyakron) düzlem olarak tanımlamıştır. Saussure, dilbilim çalışmalarında senkroni ve diyakroni kavramlaştırmasından sonra lafız (signifier, gösteren) ve anlam (signified, gösterilen) kavramları üzerinde durur. Lafız ve anlam kavramları Saussure'nin kuramının temelini oluşturmasına rağmen tasavvur, isim-müsemma ve isimlendirme gibi terimlerinin açıklanmaması yapısal teorinin önemli eksiklikleri arasındadır. Saussure her ne kadar modern dil bilimin kurucusu kabul edilse bile onun yaklaşımı İslâm âlimi Gazzâlî; hatta antik çağ filozofu Aristotales'nun çok gerisindedir. ${ }^{119}$ Saussure'nin teorisi Gazzâlî, Fârâbî, İbn Sînâ ve Ali Kuşçu gibi Müslüman dil ve mantık âlimlerinin açıkladığı çok boyutlu delâlet çeşitleri yanında da çok basit kalmaktadır. ${ }^{120}$ Bu fark, ilgili âlimlerin dil bahsindeki analiz ve sentezleri karşılaştırıldığında çok açık bir şekilde görülecektir. Örneğin Gazzâlî dilin kökeni ve mahiyetini isim-müsemmâ ilişkisi etrafında tartışırken dili "varlık tezahürlerinin nesnesi, tasavvur, lafız ve kitabet" olmak üzere dörtlü bir yapı içerisinde değerlendirmiştir. ${ }^{121}$ Birincisi, var-

119 bk. Aristotle, “De Interpretatione”, 16a 26-29; Gazzâlî, el-Müstasfâ, 180-181; Gazzâlî, Maksadü'l-esnâ, 7-10.

120 Fârâbî, el-Elfâzu'l-musta'mele fi'l-mantık, 41-43; İbn Sînâ, Kitâbu'l-işârât, 82.

121 Gazzâlî, el-Mustasfâ, 19-25; Ebû Hâmid Muhammed b. Ahmed el-Gazzâlî, Tehâfütü'l-felâsife: Filozofların Tutarsızlığı, çev. Bekir Sadak (ìstanbul: Ahsen Yayınları, 2002), 52-54; Ebû Hâmid Muhammed b. Ahmed el-Gazzâlî, Mi'yârü'l-ilm fî fenni'I-mantık (Kahire: Dârü'l-Meârif, 1961), 75. 
lık tezahürlerinin nesnesi olup "âyan" olarak adlandırılmaktadır. Ayan dış dünyada görülen bir varlığın gerçekliği ve kendisidir ki gözle görülmesinden dolayı bu ismi almıştır. İkincisi bir varlığın dış dünyadaki gerçekliğinin algılanması, zihne alınması ve zihinde tutulmasıdır. Buna imge, kavram veya tasavvur da denilmektedir. Üçüncüsü mantık ilminde terim adı verilen zihindeki kavramların, imgelerin ve tasavvurların varlığa karşılık gelen ses veya harfleridir. Bunlar toplumlara göre değişen belli harf, resim ve temsillerle gösterilen simgelerdir. ${ }^{122}$ Dördüncüsüne ise beyân adı verilen varlığın zihnindeki imgesinin açıklanması, konuşulması veya yazıya dökülmesidir. Örneğin ateşin bir öz gerçekliği; zihindeki tasavvur gerçekliği; terimsel (simgesel) gerçekliği; bir de söz ve yazıyla tezahür etmiş gerçekliği vardır. Bunların her biri diğeri için tamamlayıc bir cüz olsa da en somut olanı ateşin bizzat kendisidir. Modern dilbilimcilerin duayeni kabul edilen Saussure ise daha çok lafız-mana üzerinde durmuş; bazen varlığın bizzat gerçekliğine vurgu yapsa da onun kuramı; dil-söz ve lafız-mana vurgusuyla öne çıkmıştır.

Saussure'de Gösteren/Lafız ile Gösterilen/Mana: Saussure bir başka açıdan dili göstergeler sistemi olarak kabul etmiş; lafız ve mana olarak ikiye ayırmıştır. Dil yapısının ögeleri ve yapısalcılığın temel unsurları lafız ve manadan oluşan göstergeler veya delâletler ya da işaretlerdir. Her gösterge, gösteren ile gösterilenden oluşur. Burada gösteren (delil, lafız); bir sözcüğün akustik yapısı ve ses biçimidir. Gösterilen/medlûl/mana ise anlam ve düşüncedir. Saussure'ye göre gösteren ile gösterilen birbirleri ile ilişkili olup anlam böylece var olur; bunların her birinin diğerine var olma açısından bir önceliği yoktur ve kendi aralarındaki ilişki dışında başka bir anlama sahip değildir. ${ }^{123}$ Diğer yandan lafız ile anlam arasında hiçbir doğal ilişki de yoktur; tarihin bilinmeyen bir döneminde belli sözcükler varlıklar için kullanılmış; onlara ad olmuş ve öylece devam etmektedir. Gerçekte doğal dünyada varlıklar aynı iken pek çok dilde onların isimlendirilmesi farklılık gösterir. ${ }^{124}$ Bu görüşüyle Saussure dil teorileri içerisinde uzlaşıyı, ıstılâhîliği kabul etmiştir. "Lafız ile anlam arasında hiçbir doğal ilişki de yoktur" diyen Saussure'nin bu görüşünü kabul etmek mümkün değildir. Zira Arapçada bunun pek çok örneği vardır. Hz. Âdem'e isimler öğretildikten sonra o, lafız, anlam ve varlık arasında ilişki kurarak isimlerden haber vermiştir. Hz. Âdem, öğrendikten sonra bu isimleri harf, telaffuz, mahreç ve sıfatlarından hangi varlığa karşılık geldiğini bilmiş; sonra da bunu Allah'ın huzurunda meleklere (veya tüm canlılara) açıklamış olmalıdır. Hz. Âdem için burada ilki varlığın özellikleri; ikincisi bu varlığın özelliklerini anlatan ismi olmak üzere ikili bir bilme söz konusudur. Nitekim misal âlemi ile rüyalar âleminin açıklamaları da lafız, anlam ve varlığa göre yapılmaktadır.

Saussure'ye göre varlık sabit olsa bile gösteren ile gösterilen arasındaki bağlantı kültürden kültüre değişmektedir. Köpeğin kendisi tüm dünyada gerçek ve objektif bir varlık iken onun adlandırılması farklıdır. Maksat aynı olsa bile onun isimlendirilmesi dillere göre değişmektedir. Kültürlere göre köpeğin gerçekliği-

122 Gazzâlî, el-Müstasfâ, 19-25.

123 Saussure, Genel Dil Bilim Dersleri, 109, 110.

124 Saussure, Genel Dil Bilim Dersleri, 112; Coward ve Ellis, Dil ve Maddecilik, 29; Ayrıca bk. Güceyüz, Temel belâgat terimlerinin teşekkülü, 51-55. 
nin (müsemmâ) dışında bir gerçekliği daha vardır ki o da her dilin "köpek" anlamına gelen bir kelimesinin (isim) olmasıdır. Bu açıklamadan da dilin bir karaktere sahip olduğu ve kendine özgü bir yapısının olduğu anlamı çıkmaktadır. ${ }^{125}$ Dildeki işaretler bir anlamlandırma sonucu; gösteren ile gösterilenler arasındaki ilişkiden oluşmaktadır. ${ }^{126}$ Yapı hem düşünceleri oluşturur hem de lafız ve anlam ikilini aynı anda oluşturur. Bundan dolayı her lafız diğerlerinden farklı olduğu gibi bağlamına göre farklı anlamlara gelir.

Saussure'ye göre, dillerin nedenselliği yoktur. ${ }^{127}$ Dilin nedensizliği, hecelerin tertibi, dilin değişip değişmemesi gibi farklı özellikleri vardır. Gösterenle/lafızla varlık arasında hiçbir ilişki yoktur. Hatta lafızla anlam arasında da bir ilişki yoktur. Varlığın gerçekliği vardır ancak onun isimlendirmesi toplumdan topluma değişmektedir. Dağlarda otlayan, sarp kayalıklara çıkan süt ve etinden yararlanılan "keçi" lafzının ilgili hayvanla öz olarak hiçbir ilişkisi yoktur. Zira aynı hayvana Araplar "anz, mâiz" derken İngilizler ise "goat" derler. Eğer varlıkla isim arasında ilişki olsa idi bunlar aynı ya da yakın bir isimle anılırdı. ${ }^{128}$ Diğer yandan Saussure'ye göre, dil ve sembol birbirinden farklıdır ve semboller nedenseldir ancak dillerin nedenselliği yoktur. ${ }^{129}$ Dillerin nedensiz olduğunu söyleyen Saussure'nin bu görüşünü de kabul etmek mümkün değildir. Zira dillerde nedensellik tamamen olmasa bile lafız ile ilgili varlık arasında büyük ölçüde nedensellik vardır ki bu özellik bazı dillerde daha fazladır. Arapçaya bakıldığında pek çok konuda nedensel olduğu görülecektir. ${ }^{130}$ Örneğin Arapçada zor ve meşakkatli durumları gösteren kelimeler "gayn, şîn, hâ" gibi mahreci ve sıfatı sert harflerle ifade edilirken kolay ve rahat işleri ifade eden kelimelerde "ayn, cîm ve yâ" harfleri kullanılmaktadır. ${ }^{131}$ Bunun yanında emsilede kelimeler sîğalara göre çekimlenerek, nedensel olarak muhtelife ${ }^{132}$ ve muttaride ${ }^{133}$ adı altında benzer anlamlara sahip olabilmektedir. ${ }^{134}$ Arapçanın binâsında ${ }^{135}$ da kelimeler, kalıba göre nedensel olarak ortak anlamlara sahip olabilmektedir.

Saussure'ye göre, dillerdeki "yansıma"ların nedenselliğe örnek gösterilmesi de yanlıştır. Ona göre yansımalar açısından bile diller çeşitlilik göstermektedir. Yine bazı hayvanların çıkardığı "gak", "gulu gulu" gibi sesler nedensel olarak görülse de telaffuzu diller arasında değişmektedir. ${ }^{136}$ Saussure'ye göre, dillerin

125 Lechte, Fifty Key Contemporary Thinkers, 150.

126 Coward ve Ellis, Dil ve Maddecilik, 29.

127 Saussure, Genel Dil Bilim Dersleri, 112.

128 Şaban Köktürk ve Semra Eyri, Dilbilim ve Göstergebilim: Ferdinand de Saussure ve Göstergebilimi Anlamak. Sakarya Üniversitesi Fen Edebiyat Dergisi, 2, (2013), 123-136.

129 Saussure, Genel Dil Bilim Dersleri, 113.

130 bk. İbn Fâris, Mu'cemü mekāyîisi'l-lug̉a (nşr. Abdüsselâm M. Hârûn), Kahire: el-Bâbî el-Halebî, 1389/1969, 1/50.

131 bk. el-Gaşiye 88/1-26.

132 Arapça kelime çeşitleri.

133 Arapça her bir kelime çeşidinin zamirlere veya şahıslara göre çekimi. Örneğin "yardım etmek" bir kelime çeşidi/ muhtelife iken yardım etmenin "o yardın etti" - "o ikisi yardım etti" - "onlar yardım ettiler" gibi çekimleri ise muttaride olarak isimlendirilmektedir.

134 İsmail Durmuş, "Emsile” Türkiye Diyanet Vakfı İslâm Ansiklopedisi (İstanbul: TDV Yayınları 1995), 11/166.

135 Arapça kelime kalıpları.

136 Saussure, Genel Dil Bilim Dersleri, 114. 
özelliklerinden biri, hece tertibi yani kelimedeki harf sıralamasıdır. Onun dizgisellik/çizgisellik olarak adlandırdığı kelime tertibi dillerdeki kelimelerin belli bir ses/harf sıralamasına göre telaffuz edilmesidir. Kitap sözcüğünü "tap-ki" şeklinde söylemek anlamı bozmaktadır. ${ }^{137}$ Oysaki Sâmî dillerinde böyle bir şey yoktur. Örneğin Arapçada "a-re-fe" "öğrendi" kelimesinin harflerinin yeri değiştirilerek "ra-fe-'a" "yükseldi"; "fe-ra-'a" "ayrıntılandırdı" gibi kelimeler elde edildiğinde "öğrendi" anlamını hiçbir zaman kaybetmemektedir. ${ }^{138}$ Yine "a-le-me" "bildi"; "a-me-le" "çalıştı"; "le-me-a" "aydınlattı" ve "ra-ce-me" "taşladı"; "ce-me-ra" "sıcak oldu, taşladı" "ce-ra-me" "suç işledi"; "me-ra-ce" "salıverdi" anlamlarına gelmekte ve her durumda da anlamlar birbiriyle bağlantılı olmaktadır. Saussure dilin değişip değişmemesi gibi konulara değinmiş ve dilin sabit ve değişmez gibi bir yapısının olduğu halde sürekli değişim ve dönüşüm geçirdiğini kabul etmiş̧tir. ${ }^{139}$ Değişimi sağlayan birey değil toplumların kendileridir. Diğer yandan değiş̧im bir anda olmayıp belli kurallar dâhilinde ve süreç içerisinde gerçekleşmektedir.

\subsubsection{Roland Barthes'de Dil}

Semiyoloji Saussure'nin de etkisiyle 1960'lardan sonra toplum bilimlerinde, kültür ve kitle iletişim araştırmalarında popüler olmuştur. Semiyoloji, Fransa'da ortaya çıkıp daha sonra diğer ülkelere yayılarak toplumdaki işaretlerin bilimi olarak tanımlanmıştır. ${ }^{140}$ Barthes, (ö. 1980) Saussure'nin yapısalcı dilbilim çalışmalarına katkı yaparak semiyolojiyi geliştirmiş ve bir bilim olmasını sağlamıştır. ${ }^{141}$ Barthes, yapısalcılığın temelini dil bilim ile semiyolojinin oluşturduğunu kabul etmiştir. ${ }^{142}$ Barthes, semiyoloji alanında uzmanlaşarak dil dahil bütün simge, sembol ve işaretlerin semiyolojiye dâhil edilmesini söyleyerek kültürü delâlet kapsamına almıştır. Hatta o, semiyoloji ile sosyal antropoloji arasında bir karşılaşma yapmış ve semiyolojinin antropolojiden daha genel olduğunu iddia etmiştir. Çünkü sosyal antropoloji sadece kültürel ve toplumsal konuları incelerken bunlara ilaveten beslenme alışkanlıkları ile dinlenme şekillerini incelemektedir. ${ }^{143}$

Barthes ile Saussure karşılaştırıldığında dil ve gösterge konusunda birbiriyle karşıt oldukları görülür. Barthes dil tanımını daha geniş tutarak tüm işaretleri kapsadığını ifade ederken Saussure ise göstergenin daha geniş ve şümullü olduğunu ifade etmektedir. Barthes'e göre semiyoloji ya da dil; işaretlerin bilimidir ve başta konuşma dili, el, kol, kas hareketleri ile ritimli sesler, bazı eşyalar, her türlü merasim ve gösterileri kapsamaktadır. Barhes'e göre semiyoloji içerisinde değerlendirilen el, kol, kas hareketleri, ritimli sesler, eşyalar ve törenler sözsüz olsa bile dil olarak değerlendirilmelidir. Buna göre Barthes'in dille semiyolojiyi eş anlamlı olarak kullandığı anlaşılır. Zira yiyecek, giyecek ve barınma gibi ihtiyaçların bir

137 Saussure, Genel Dil Bilim Dersleri, 115

138 bk. Mecdüddîn Fîrûzabâdî, el-Kāmûșu'l-muhîț (Beyrût: Müessesetü'r-Risâle, 1408/1987), 933, 964, 1080.

139 Saussure, Genel Dil Bilim Dersleri, 116, 17.

140 Coward ve Ellis, Dil ve Maddecilik, 50.

141 Anthony Giddens, Sosyoloji, çev. Cemal Güzel (Ankara: Ayraç Yayınları, 2000), 596.

142 Swingewood, Sosyolojik Düşüncenin Kısa Tarihi, 356.

143 J. Sturrock, Structuralism (London: Blackwell, 2003), 74. 
anlamı vardır ve dizge hallerini ve açıklamalarını dille gerçekleştirir. ${ }^{144}$ Zira her gösterge dizgesi dille alakalı olup sürekli dille yapısal bir ilişki içerisindedir. Saussure ile Barthes, filozof ve mantıkçılardan Fârâbî ve İbn Sînâ ile karşılaştıııldığında Saussure'nin Fârâbî ve İbn Sînâ'ya daha yakın olduğu görülür. Zira Saussure de İslâm filozofları gibi göstergenin/delâletin dilden daha genel olduğunu ifade etmiştir. Barthes'in işaret ve simgelerine gelince İslâm filozoflarına göre bunlar delâlet/işaret olarak adlandırılmakta lakin dil olarak kabul edilmemektedir.

Modern bilim insanlarıyla İslâm âlimleri karşılaştırıldığında Müslümanların dil teorilerinin daha mükemmel ve daha kapsamlı olduğu görülecektir. Örneğin Fârâbî'ye göre, delâlet/gösterge lafzî/sözle ve lafzî olmayan/sözsüz olmak üzere ikiye ayrılır. "Kitap" kelimesinin yazılı ve iki kapak arasındaki metne işaret etmesi lafzî; dumanın yanmakta olan bir ateşe işareti de lafzî olmayan aklî delâlettir. Ona göre delil ile medlûl arasındaki bağ akılla kurulur. Bu bağ, bazen zihnin makulleriyle bazen de duyular vasıtasıyla sağlanan tecrübe, görgü ve bilgi gibi insanlar arası ortak iletişim verileriyle kullanılır. Delâlet lafzî ve gayr-i lafzî tasnifine girmeksizin aklî, doğal ve vaz'î olmak üzere başlıca üçe ayrılır. ${ }^{145}$ Lafzî ve gayr-i lafzî delâletlerin her bir grubu da kendi içerisinde aklî, doğal ve vaz'î olarak üçe ayrılmakta ve toplam altı çeşit olarak incelenmektedir. Lafzî delâletin aklî, doğal ve vaz'î; gayr-i lafzî delâletin de aklî, doğal ve vaz'î işaretleri vardır. Bir duvarın arkasından gelen "oley" sesi orada bir insanın olduğuna işaret ettiği için lafzî aklî; dumanın çıktığı yerde ateşin olması aklî gayr-ı lafzî delâlettir. Yine zor durumdaki bir insanın "of, puf" demesi lafzî doğal delâlet; yüzünün kızarması ise gayr-i lafzî doğal delâlettir. Vaz'î olarak da adlandırılan beşerî delâletler ise dil ile bazı jest ve mimiklerdir. Örneğin baş sallamak dünyanın pek çok dilinde "kabul" manasına gelmektedir. Fârâbî ve İ̉n Sînâ mantık ilminde vaz'î lafzî delâletin diğer delâletlere üstünlüğü üzerinde durmuşlardır. Zira diğer delâletler yoruma açık olup söz kadar bir kesinlik taşımazlar. ${ }^{146}$ Saussusre, Fârâbî ve İbn Sînâ çizgisinde delâlet içerisinde dili ele alırken Barthes ise tam tersi bir şekilde dilin tüm göstergeleri kapsadığını iddia eder. Mantıkçılar ise bu delâlet çeşitleri arasında dil olarak adlandırılan beşerî/lafzî vaz'î delâletin en güvenilir ve geçerli olduğunu söylemişlerdir.

Semiyoloji başta dil olmak üzere diğer göstergeleri ve toplumsal anlamı düzenli bir şekilde inceler. Zira semiyolojide kültürel kodlar ile toplumsal güç ilişkileri de ele alınır. Zira kültürel kodlar ile toplumsal güç ilişkileri arasında sıkı bir bağ vardır. Bu nedenle o, burjuva toplumundaki güç ilişkileri ile kültürel kodların nasıl kurulduğunu açıklamıştır. ${ }^{147}$

Barthes'de Düz Anlam ve Yan Anlam: Barthes bir dilde düz ve yan olmak üzere başlıca iki anlam olduğunu belirtmiş; düz anlamı bir nesnenin karşılığı olarak açıklamıştır. Çorba, sıvı bir içeceği; ekmek temel gıda maddesini, eğlence ise

144 Serpil Sancar Üşür, İeolojinin Serüveni Yanlış Bilinçve Hegemonyadan Söyleme (Ankara: İmge Kitapevi, 1997), 80.

145 Fârâbî, el-Elfâzu'l-musta'mele fi'l-mantık, 41-43

146 Fârâbî, el-Elfâzu'l-musta'mele fi'l-mantık, 41-43; ibn Sînâ, Kitâbu'l-işârât, 82.

147 Coward ve Ellis, Dil ve Maddecilik, 50. 
keyifli vakit geçirmeyi karşılamaktadır. Yan anlam ise doğrudan bir varlık değil de onun dışında başka şeyler kastedilir. Zira yan anlamda işaret, söz veya lafız düz manasını aşarak farklı anlamları kasteder. Yan anlam, bir işaret veya bir lafzın düz anlamı ifade eden gösterge aracılığıyla başka anlamları ifade etmesidir. ${ }^{148}$ Çorba ve ekmek kelimelerinin çorba ve ekmek dışında "para kazanmak ve geçimini sağlamak için gelir elde etmek" anlamları da vardır. Bir yemek çeşidi olan "çorba"ya işaret eden "ç-o-r-b-a" sesleri gösteren/lafız, yemeğin adı ise "gösterilen" dir; "çorba" sözcüğünün para kazanmak anlamında kullanıldığında ise "çorba" sözcüğü "gösteren", para kazanmak "gösterilen"dir. Düz anlamda kelime bir varlığa işaret ederken yan anlamda o varlık başka bir eylemi karşılamaktadır. Bir lafız, bir varlığı doğrudan karşılamak için kullanılıyorsa düz anlam/gerçek/hakiki anlam; gerçek anlamı dışında başka şeyleri açıklamak için kullanılıyorsa yan anlam denir. Yan anlam İslâm literatüründe beyan olarak açıklanmış ve kinaye, mecaz, istiare ve teşbih gibi çeşitlerinin olduğu belirtilmiştir. ${ }^{149}$ "Çorba"yla sadece "sıvı içecek" anlatılırsa gerçek anlam; ekmek parası anlatılırsa "mecaz anlam"; hem çorba hem de ekmek parası ikisi birden kastedilirse kinaye olmuş olur.

Barthes düz anlam ve yan anlam konusunda dil tahlillerinin yanı sıra resimleri de incelemiştir. Paris-Match dergisindeki bir resimde Fransa bayrağını selamlayan bir siyahi çocuk resmi onun çok dikkatini çekmiş̧tir. Bu resimdeki çocuk ona göre sadece bir çocuğun bayrağı selamlaması değildir. Bu resim; ilk görüşte siyahi bir çocuğun Fransız bayrağını selamlaması olarak görülse de aslında sömürgeci ulusçuluk ile militarizm birlikteliği anlamına gelmektedir. Burada düz anlamın ardında yan anlamlar gizlidir ki çoğu zaman ikinciler daha çok şey anlatabilmektedir. ${ }^{150}$

Barthes'e göre mitolojiler de dil bağlamında değerlendirilecek olgulardır. Mitolojiler bir toplumun doğayı ve kendini tanımlaması; dünyayı ve varlığı anlamlandırması ve kavramsallaştırmasıdır. Bu anlamlandırma ve kavramsallaştırma da kendini dilde gösterir. Mitoloji de dil sisteminin özel bir alanı olup dilin hakiki ve mecaz anlamlarının doğal ve ebedi olduğunu gösterir. ${ }^{151}$ Örneğin burjuva kültürü de tabi bir süreç gibi ortaya çıkan bu mitolojiler ve ideolojiler tarafından oluşmuştur. ${ }^{152}$ İslâmî ilimlerin köken dille ilgili açıklamalarının temelini dinî kaynaklar oluştururken Barthes'in görüşlerinin temelini birtakım gözlem ve analizler oluşturur. İslâm âlimleri ise Hz. Âdem'e öğretilen isimleri daha çok kelâmî bir okumayla dil olarak açıklamışlardır. Bu nedenle toplum bilimleri içerisinde yer alan ve kevnî bir okumaya sahip olan sosyoloji, psikoloji, semiyoloji ve dil bilim verilerine müracaat edilmiştir. Araştırma sonucunda görülmüştür ki sosyoloji, psikoloji, semiyoloji ve dil bilim insanları insan ve toplum için en önemli kurumun dil olduğunu beyan etmişlerdir. Bu da İslâm âlimlerinin ta'lîmü'l-esmâ âyetini dil olarak açıklamalarını haklı çıkarmakta ve kevnî bir ispatını oluşturmaktadır.

148 Coward ve Ellis, Dil ve Maddecilik, 50.

149 Nasrullah Hacımüftüoğlu, "Beyân”, Türkiye Diyanet Vakfı İlâm Ansiklopedisi (ìstanbul: TDV Yayınları 2013), 6/22.

150 Coward ve Ellis, Dil ve Maddecilik, 54.

151 Coward ve Ellis, Dil ve Maddecilik, 56.

152 Swingewood, Sosyolojik Düşüncenin Kısa Tarihi, 357. 


\section{Sonuç}

Dilin nasıl ortaya çıktığı ve geliştiği problemi tarihin ilk dönemlerinden beri sorgulanmıştır. İslâm âlimlerine göre köken dil; Hz. Âdem'e ya bizzat Yüce Allah tarafından öğretilmiş ya da Yüce Allah'ın insana lütfettiği kabiliyet neticesinde insanlar tarafından oluşturulmuştur. Ta'lîmü'l-esmâ âyetine bakıldığında Yüce Allah'ın Hz. Âdem'e sadece isimleri öğrettiği bildirilse de yaratılış kıssasında Hz. Âdem'in bir dil konuştuğu; bu dille isimlerden haber verdiği; bu dille emir ve yasaklara muhatap kılındığı; Rabbinden kelimeler aldığı; tövbe ettiği; çocuklarına ve ailesine dinî tebliğ ettiği bildirilmektedir. Bundan da anlaşılmaktadır ki Hz. Âdem, iletişim aracı olarak bir dil konuşmaktadır. Yaratılış teorisinin önemli olmadığı seküler ve modern kuramlarda ise dil, sadece deneysel ve aklî verilerle açıklanmaya çalışılmıştır. İslâmî ilim ile modern bilim, farklı ontoloji, epistemoloji ve metodolojiye sahip olsa da dil teorisi konusunda bazı noktalarda yakın görüşlere sahiptir. Örneğin İslâm'daki ıstılâhî teorinin, modern bilimlerdeki sözleşme veya uzlaşı kuramına yakın olduğu söylenebilir.

İslâm'daki tevkîfîlik, ıstılâhîlik ve meleke teorisi karşısında modern bilimlerde doğalcılık, uzlaşı ve potansiyel dil teorileri yer almaktadır. Modern bilimler genelde dini ve dinî verileri inkâr ettikleri için tevkîfîlik teorisini baştan kabul etmemektedirler. Ancak İslâmî ilimlerdeki ıstılâhîlik teorisi modern bilimlerde uzlaşı kuramına; meleke teorisi de potansiyel teorisine benzemektedir. Modern bilimlerde potansiyel teorisi Chomsky'nin dilin temel gramer kurallarının bütün insanlarda benzer olduğu tezine dayanmaktadır. İnsanlarda biyolojik anlamda dil yetisi vardır. Dil yetisi konusunda insanlar aynı veya benzer fıtrî özelliklere sahiptir; ancak insanlar kültürlerine göre farklı kelimeler ve semboller kullanmaktadırlar. Aslında bu açıklama daha önce Fârâbî ve İbn Haldûn tarafından dile getirilmiştir. Buna göre potansiyel dil teorisi aslında ilk defa Chomsky tarafından ortaya konmamıştır.

Modern bilimler; dilin kökeni ile gelişimini tam olarak açıklayamamaktadırlar. Zira onlar bilimsel yöntemlerinde sadece deney ve gözlemin kullanıldığı ampirizmi kabul etmektedirler. Bu nedenle onların tarihin başlangıcına gidip dilin nasıl ortaya çıktığına dair bir gözlem ve deneyim yaşamaları mümkün değildir. Bu durumda yapılan şey sadece somut veriler bulmak ve dilin kökenine dair varsayımlar üretmektir. Aynı zamanda bunlar dinî verileri de inkâr ettikleri için ilâhî bilgiden mahrum kalmakta; dil konusunda ilk insana kadar geri gidememekte; mevcut durumu gözleyerek birtakım sonuçlar çıkarmaktadırlar. Bu sebeple onlar, dili konuşma dahil simge ve sembol üretiminin tamamı olarak açıklanmaktadır. Modern bilimlere göre dil sadece lafız ve anlamlardan oluşmamakta; el-kol hareketleri, jest ve mimikler, resimler ve şekillerde dil kapsamında ele alınmaktadır. Modern bilimcilerin bu dil tarifinin tam karşılığı İslâm âlimlerine göre dil değil delâlet veya işarettir. İslâm âlimlerine göre dil ile delâlet arasında umum husus farklılığı vardır. Delâlet dil dahil tüm göstergeleri kapsadığı için umum bir mana ifade ederken dil işaretler içerisinde sadece belli bir bölümü oluşturmakta; 
hususî bir anlam ifade etmektedir. Buna göre İslâm âlimlerinin delâlet dediğine modern bilimler dil demektedir. Modern bilimlerinin delâleti genel olarak dil olarak kabul etmeleri toplumsal hayatta pek çok anlaşmazlığa ve hukukî sıkıntıya sokacaktır. Zira İslâm âlimlerine göre eylem, resim, gösterge, işaret, susma, durum, renk, jest ve mimiklerin belli bir anlamı olsa da bunlar mantığın ve hukukun dışındadır. Bunun yanında lafzî delâletler içinde aklî ve doğal delâletler de mantığın ve hukukun dışında tutulmaktadır. Çünkü aklî delâlet olan bir engelin arkasındaki ses; çoğu zaman manayı değil de sahibini tanıtır. Bu delâlette duyulan sese anlam vermekten ziyade "bu falanca kimsenin sesi" denilerek sahibi tanıtılır. Seslerin başka insanlar tarafından taklit edildiği için lafzî-aklî delâlet mantık ve hukuk açısından da yanıltıcı olabilmekte ve haksızlıklara yol açabilmektedir. Bununla birlikte insanların zekâ ve anlayışları farklı olduğu için dil harici işaretlerde mutlak anlamda bir mutabakat sağlanamamaktadır. Söze dayalı dil içerisinde bile pek çok yanlış anlamaların olduğu düşünüldüğünde, bunun simge ve sembollerle oluşması daha olanaklıdır. Bu nedenle klasik mantıkta gösterge anlamına gelen delâlet; lafzî aklî, lafzî tabiî ve lafzî vaz'î delâlet ile gayr-i lafzî aklî, tabiî ve vaz'î delâlet olarak altı çeşide ayrılsa da bunlar içerisinde sadece dil anlamına gelen lafzî vaz'î delâlet mantık ve hukuk ilminin konusuna girmektedir. Lafzî vaz'i delâletle ifade edilen sözlerde bile anlamın sabitlenmesi her zaman için mümkün değildir. Zira hangi dil olursa olsun yanlış anlamaya imkân vermeyecek şekilde her bir sözcüğün açıı bir biçimde anlaşılması olanak dışıdır. Eğer böyle olsaydı dinî ve hukukî metinlerde (Arapça) lafız-mana ilişkisinin sabitlenmesi ve her türlü farklı anlamaların ortadan kalkması gerekirdi. Hal böyle olsa da delâlet çeşitleri içerisinde en güvenilir olanı lafzî vaz'î delâlettir. 


\section{Kaynakça}

Aksan, Doğan. Her Yönüyle Dil: Ana Çizgileriyle Dilbilim. Ankara: Türk Dil Kurumu, 2003.

Aristotle. "De Interpretatione", Complete Works. Digital Edition, ed. Jonathan Barnes, New Jersey: Princeton University Press, 1995, 16a 26-29.

Aster, Ernst Von. Bilgi Teorisi ve Mantık. çev. Macit Gökberk, İstanbul: Mehmet Sadık Kağıtçı Matbaası, 1945.

Arvas, Hamdullah. "Kelâm'da "Ta'lîm-i Esmâ": Dil Teorileri Bağlamında Illâhî Mânaların İsimlendirilmesi Meselesi", Kader 18/2 (Aralık 2020), 500-538.

Bağdâdî, Ebû Mansûr Abdülkāhîr. el-Fark beyne'l-firâk ve beyâni'l-firaki'n-nâciye. Beyrut: Dârü'l-Afâk Şâmile, 1977.

Bâkıllânî, Ebû Bekr Muhammed b. Tayyib. et-Takrîb ve'I-irşâd. Müessesetü'r-Risâle, 1998.

Berger, Peter ve Luckmann, Thomas. Gerçekliğin Sosyal Inşası: Bir Bilgi Sosyolojisi Incelemesi. çev. Vefa Saygın Öğütle, İstanbul: Paradigma Yayıncılık, 2008.

Bernard N. Meltzer; John W. Petras; Larry T. Reynolds, Symbolic Interactionism: Genesis, Varieties an Criticism. London: Routledge and Kegan Paul, 1975.

Beyzâvî, Kādî Nasîrüddîn. Envâru't-tenzîl ve esrâru't-te'vîl. Beyrût: Dâru'l-Kütübi'l-'ilmiyye, $1431 / 2011$.

Blumer, Herbert. Symbolic Interactionism: Perspective and Method. Englewood Cliffs, New Jersey: Prentice-Hall Inc,. 1969.

Condon, John C. Kelimelerin Büyülü Dünyası: Anlambilim ve Iletişim. çev. Murat Çiftkaya, İstanbul: İnsan Yayınları, 2000.

Coward, Rosalind. ve Ellis, John. Dil ve Maddecilik. çev. Esen Tarım, İstanbul: Illetişim Yayınları, 1985.

Cürcânî, Ali b. Muhammed. Şerhu'l-mevâkıf. İstanbul: Dârü't-Tıbâati'l-Âmire, 1321/1905.

Cüveynî, Ebü'l-Meâlî Rüknüddîn Abdülmelik b. Abdillâh b. Yûsuf. el-Irşâd. thk. Saîd Temîm, Beyrut: Müesseseti'I-Kütübü's-Sekāfe, 1416.

Demir, Ramazan. Arap Dilbilimcilerine Göre Dillerin Kaynağı Meselesi: Hz. Âdem'in Dili. İstanbul Hâcegân Akademi Kitaplığı, 2009.

Durkheim, Emile. The Rules of Sociological Method. New York: Free Press, 1982.

Durmuş, İsmail. "Emsile" Türkiye Diyanet Vakfı İslâm Ansiklopedisi. İstanbul: TDV Yayınları 1995. 11/166.

Ellul, Jacques. Sözün Düşüşü. çev. Hüsamettin Aslan, İstanbul: Egin Yayınları, 2012.

Eriksen, Thomas Hylland. Kültür Terörizmi: Kültürel Arınma Üzerine Bir Deneme. çev. Önder Otçu, Diyarbakır: Avesta Yayıncılık, 2000.

Fârâbî, Ebu Nasr. el-Elfâzu'l-musta'mele fi'l-mantık. thk. Muhsin Mehdi, Beyrut: Dâru'lMeşrik, 1968.

Fârâbî, Ebu Nasr. Harfler Kitabı. çev. Ömer Türker, İstanbul: Litera Yayınları, 2008.

Fîrûzabâdî, Mecdüddîn. el-Kāmûșu'I-muhît. Beyrût: Müessesetü'r-Risâle, 1408/1987.

Foucault, Michel. The Archeology of Knowledge. New York: Random House, 1972.

Freud, Sigmund. Yaşamım ve Psikanaliz. İstanbul: Say Yayınları, 1997.

Gazzâlî, Ebû Hâmid Muhammed b. Ahmed. el-Müstasfâ. thk. Muhammed Abdüsselâm, Dârü'l-Kûtûbi'I-IIImiyye, 1993.

Gazzâlî, Ebû Hâmid Muhammed b. Ahmed. Maksadü'l-esnâ fi şerhi meâni esmâillahi'lhüsnâ. thk. Bessam Abdulvahab el-Camî, Kıbrıs: el-Cifan ve'l-Cabi, 1987. 
Hz. Âdem'e Öğretilen İsimler: İslâmî İlimlerde Dilin Kökeni, Modern Bilimlerde Dilin Önemi

Geertz, Clifford. Kültürlerin Yorumlanması. çev. Hakan Gür, Ankara: Dost Kitabevi Yayınları, 2010.

Giddens, Anthony, Sosyoloji. çev. Cemal Güzel, Ankara: Ayraç Yayınları, 2000.

Güceyüz, İsa. Temel belâgat terimlerinin teşekkülü: fesahat, belâgat, meânî, beyân ve bedî’ . Erzurum: Atatürk Üniversitesi, Sosyal Bilimler Enstitüsü, Doktora Tezi, 2020.

Gündüzöz, Soner. Arapça'da Kelime Türetimi. Samsun: Din ve Bilim Kitapları Yayıncılık, 2005.

Hacımüftüoğlu, Nasrullah. "Beyân", Türkiye Diyanet Vakfı İslâm Ansiklopedisi. İstanbul: TDV Yayınları 2013. 6/22-623.

Haralambos, Michael. ve Holborn, Martin. Sociology: Themes and Perspectives. London: Harper Collins, 1995.

Hicâzî Muhammed Mahmûd. et-Tefsîru'I-vâdıh. Beyrut: Dâru'l-Cîli'I-Cedîd, 1413.

İbn Cinnî. el-Hasâis, nşr. Muhammed Ali en-Neccâr, Beyrut: Dâru'I-kitâbi'l-Arabî, 1376/1956.

İbn Fâris, Mu'cemü meḳāyîsi'l-lug̉a. nşr. Abdüsselâm M. Hârûn, Kahire: el-Bâbî el-Halebî, 1389/1969.

İbn Furek, Muhammed b. Hasan. Mücerred makâlâti'ş-şeyh Ebi'l-Hasen el-Eş'arî. thk. Daniel Gimaret, Beyrut: Dâru'l-Meşrik, 1987.

İbn Haldûn, Muhammed b. Muhammed b. Hasen el-Hadramî el-Mağribî. Mukaddime. çev. Süleyman Uludağ, İstanbul: Dergâh Yayınları, 2009.

İbn Hazm, Ali b. Ahmed. el-Fasl fi'l-ehvâ ve'l-milel ve'n-nihal. Beyrut: Dârü'l-Ma'rife, 1975.

İbn Sînâ. Kitâbu'l-işârât/Les Livres des directives et remarques. çev. A. M. Goichon, Paris/ Beyrut: Librairie Philosophique J. Vrin 1951.

İbn Teymiyye, Takıyyüddîn Ahmed b. Abdilhalîm b. Mecdiddîn Abdisselâm. Kitâbü'l-Îmân. Amman: Dârü'l-Beşîr, 1996.

Kādî Abdülcebbâr, Ebü'l-Hasen. el-Muğnî fi ebvâbî tevhîd ve'l-adl. thk. İbrâhim Ebyarî, Kahire: Dârü'l-Mısriyye, 1958.

Kādî Abdülcebbâr, Tenzîhü'l-Kur'ân ani'l-metâin. Beyrut: Dâru'n-Nahde, ts.

Kahraman, Ferruh. "Hazreti Âdem'e Öğretilen İsimler: İnsanoğlunun Gerçek Mahiyetinin Tezâhürü", Balıkesir Ilahiyat Dergisi 11/1 (Haziran 2020), 39-63.

Kahraman, Ferruh. "Hz. Âdem'e Öğretilen İsimler: Kültür Olgusunun Sembolik Söylemi”, Edebali Islamiyat Dergisi 4/2 (Kasım 2020), 15-40.

Kıran, Zeynel - Kıran, Ayşe. Dilbilime Giriş. Ankara: Seçkin Yayınları, 2018.

Kitâb-ı Mukaddes. İstanbul: Kitab-ı Mukaddes Şirketi, 2003. Yaratııı̧ 02/19-20.

Köktürk, Şaban. ve Eyri,Semra. Dilbilim ve Göstergebilim: Ferdinand de Saussure ve Göstergebilimi Anlamak. Sakarya Üniversitesi Fen Edebiyat Dergisi. 2, (2013). 123-136.

Lacan, Jacques. My teaching. İngiltere: Verso Press, 2008.

Lechte, John. Fifty Key Contemporary Thinkers. London: Routledge, 1994.

Markova. "Doğunun ve Batının Yerelliği", Sosyal Temsiller ve Demokrasi. ed. Sibel Ayşen Arkonaç, İstanbul: Alfa Yayınları, 2004.

Mâtürîdî, Ebû Mansûr. Kitâbü't-Tevhîd. thk. Fethullah Huleyf, Beyrut: Dârü'l-Meşrik, 1980.

Mâtürîdî, Ebû Mansûr. Te'vîlâtü ehli's-sünne. thk: Fatıma Yûsuf el-Haymî, Beyrût: Müessesetü'r-Risâle, 1424/2004.

Mâverdî, Ebü'l-Hasen Alî b. Muhammed b. Habîb el-Basrî. Edebü'd-dîn ve'd-dünya. Dimeşk: Dârü'l-Ibni'l-Kesîr, 2008. 
Mead, George Herbert. Mind, Self and Society. Chicago: Chicago University Press, 1934. Muḳātil b. Süleymân, Tefsîru Muḳātil b. Süleymân. Beyrût: Dâru Ihyâai't-Türâsi'l-'Arabî, 2002. Nesefî, Ebü'l-Muîn. Tabsıratü'l-edille fî ûsûli'd-dîn. thk. Hüseyin Atay, Ankara: Diyanet İşleri Başkanlığı Yayınları 2003.

Özlem, Doğan. Bilim Felsefesi. İstanbul: Notos Yayınları, 2019.

Plato. "Cratylus", Complete Works: Dijital Edition, ed. John M. Cooper, Indianapolis: Phackett Publishing Company, 1997. 384a, 387c-d, 435d-e.

Plummer, Ken. Herbert Blummer Key Sociological Thinkers. Der., R. Stones, New York: Mcmillan, 2008.

Poloma, Margeret M. Çağdaş Sosyoloji Kuramları. çev. Hayriye Erbaş, Ankara: Gündoğan Yayınları, 1993.

Râfi', Mustafa Sâdık. Târihu edebi'l-Arab. Beyrut: Dâru'l-kitâbi'l-Arabî, 1999.

Râzî, Fahreddîn. el-Mahsûl. thk. Tâhâ Câbîr, Beyrut: Müessesetü'r-Risâle, 1997.

Râzî, Fahreddîn. Mefâtihü'l-gayb. Beyrut: Dârü'l-ihyyâi't-Tûrâs, 1420.

Ritzer, George. Sosyoloji Kuramları. çev. Himmet Hülür, Ankara: Deki Yayınları 2014.

Sabûnî, Muhammed Ali. Tefsîru'l-Fâtiha ve'l-Bakara. Arabistan: Dâru İbn Cevzî, 1423.

Saussure, Ferdinand de. Genel Dil Bilim Dersleri. çev. Berke Vardar, Ankara: Birey ve Toplum Yayınları, 1985.

Slattery, Martin. Key Ideas in Sociology. London: Mcmillan, 1991.

Sturrock, J. Structuralism. London: Blackwell, 2003.

Süyûtî, Ebû Bekr b. Muhammed el-Hudayrî. el-Müzhir fi ulûmi'l-luga ve envâi'hâ. Beyrut: Dârü'l-Kütübi'l- 'Illmiyye, 1998.

Swingewood, Alan. Sosyolojik Düşüncenin Kısa Tarihi. çev. Osman Akınhay, Ankara: Bilim ve Sanat Yayınlar 1998.

Taberî, İbn Cerîr, Câmiü'I-beyân. Beyrût: Dâru'I-Kütübi'l-'Illmiyye, 2009.

Tatılıcan, Ümit. ve Çeğin, Güney. Bourdieu ve Giddens: Habitus veya Yapının Ikiliği. der: Güney Çeğin, vd., İstanbul: İletişim Yayınları, 2007.

Teftâzânî, Sa'düddîn Mesu'd b. Ömer. Şerhü'l-Makāsıd. thk. Abdurrahmân Umeyr, Kum: yy, 1371.

Tura, Saffet Murat. Freud'dan Lacan'a Psikanaliz. İstanbul: Ayrıntı Yayınları, 1996.

Üşür, Serpil Sancar. İdeolojinin Serüveni Yanlış Bilinç ve Hegemonyadan Söyleme. Ankara: İmge Kitapevi, 1997.

Wittgenstein, Ludwig. Felsefi Soruşturmalar. çev. Deniz Kanıt, İstanbul: Totem Yayıncılık, 2006.

Yaqoob, Luay Hatem. "islâmî Kaynaklar Açısından Peygamberlerin Konuştuğu Diller" Cumhuriyet Ilahiyat Dergisi 25/1 (Haziran 2021), 385-407.

Zeccâc, Ebû İshâk Ibrâhîm b. es-Serîb. Sehl. İstikaku esmâillah. thk. Abdul Hüseyin Mübarek, Beyrut: Müessesetü'r-Risâle, 1986.

Zıllıoğlu, Merih. İletişim Nedir? İstanbul: Cem yayınları, 1996. 